\title{
8
}
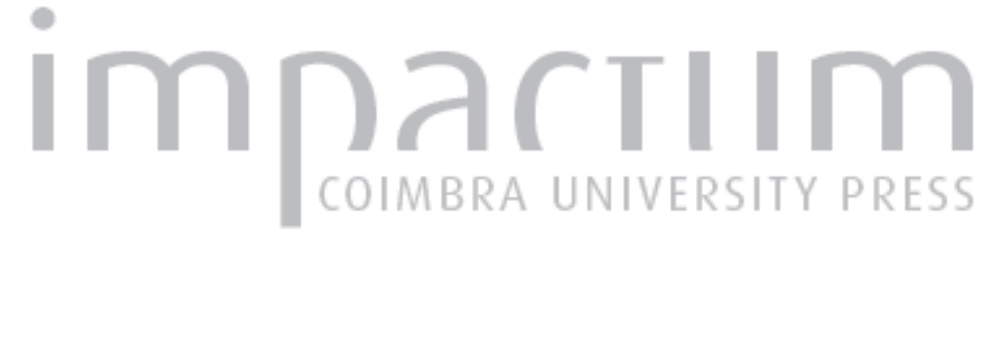

\section{A Igreja, o Estado e a questão da violência sobre os escravos: reflexões a partir do Bispado do Rio de Janeiro (1676-1785)}

Autor(es): $\quad$ Pereira, Ana Margarida Santos

Publicado por: Instituto de História Económica e Social; Imprensa da Universidade de

URL

persistente:

URI:http://hdl.handle.net/10316.2/44499

DOI: $\quad$ DOI:https://doi.org/10.14195/0870-4147_37_7

Accessed : $\quad$ 26-Apr-2023 16:23:51

A navegação consulta e descarregamento dos títulos inseridos nas Bibliotecas Digitais UC Digitalis, UC Pombalina e UC Impactum, pressupõem a aceitação plena e sem reservas dos Termos e Condições de Uso destas Bibliotecas Digitais, disponíveis em https://digitalis.uc.pt/pt-pt/termos.

Conforme exposto nos referidos Termos e Condições de Uso, o descarregamento de títulos de acesso restrito requer uma licença válida de autorização devendo o utilizador aceder ao(s) documento(s) a partir de um endereço de IP da instituição detentora da supramencionada licença.

Ao utilizador é apenas permitido o descarregamento para uso pessoal, pelo que o emprego do(s) título(s) descarregado(s) para outro fim, designadamente comercial, carece de autorização do respetivo autor ou editor da obra.

Na medida em que todas as obras da UC Digitalis se encontram protegidas pelo Código do Direito de Autor e Direitos Conexos e demais legislação aplicável, toda a cópia, parcial ou total, deste documento, nos casos em que é legalmente admitida, deverá conter ou fazer-se acompanhar por este aviso. 


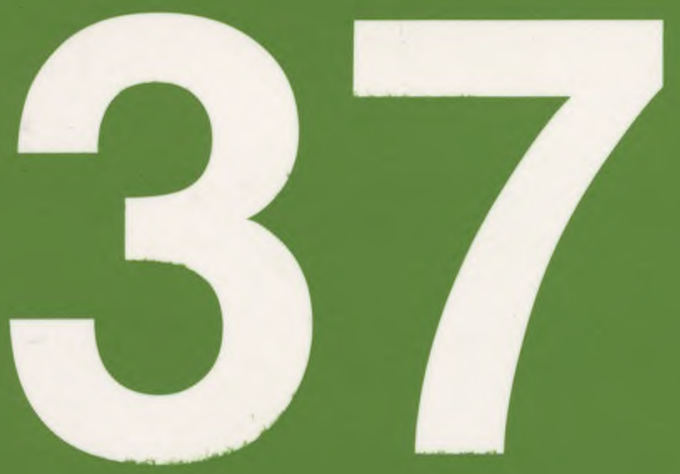

Revista Portuguesa de História

Faculdade de Letras da Universidade de Coimbra Instituto de Historia Econónica e Samial

Coimbra 05 
Revista Portuguesa de Historia

t. XXXVII (2005)

pp. $153-187$

\section{A Igreja, o Estado e a questão da violência sobre os escravos. Reflexões a partir do Bispado do Rio de Janeiro (1676-1785)}

ana Margarida Santos Pereira

Bolseira da FCT

Senhores, eu não pretendo que deis liberdade aos vossos servos; que quando o flzesseis,farieis o que flzerão os verdadeiros Christãos. $O$ que só pretendo de vós, he que os tratteis como a proximos, e como a miseráveis: que lhes dei[s] o sustento para o corpo, e para a alma: que lhes deis sómente aquele castigo, que pede a razão: e que lhes deis o trabalho tal, que possão com elle, e os não oprima. Isto só vos p[eçlo, isto só espero, e isto só quero de vós: Panis, \& disciplina, \& opus servo.

Jorge Benci, Economia Cristã dos Senhores no

Governo dos Escravos

\section{Introdução}

Em 1738 foi presa em Minas Gerais uma negra, Luzia da Silva Soares, acusada por diversas testemunhas de praticar feitiços, com o intuito de infligir sofrimento e, em última análise liquidar, tanto os seus senhores como alguns *

* Doutoranda Univ. Coimbra, Portugal \& Univ. van Amsterdam, Holanda. Bolseira da Fundação para a Ciência e a Tecnologia. 
membros da sua família, e ainda certo número de escravos, tal como aqueles vítimas dos poderes ocultos da sua jovem parceira. Uma vez interrogada, confessou de imediato a veracidade das acusações, com tal profusão de detalhes que os inquisidores não tiveram dúvidas em mandá-la vir para os cárceres do Santo Ofício, a fim de ser processada e castigada de acordo com a gravidade das suas culpas. No entanto, apesar das evidências colhidas nos depoimentos das testemunhas e da sua própria confissão, a ré acabaria por ser absolvida, numa decisão pouco habitual e até mesmo surpreendente, cuja justificação se encontra nas revelações sobre os maus tratos de que fora vítima. As descrições fornecidas pela própria das torturas a que a haviam repetidamente submetido são um testemunho pungente sobre a violência gerada no interior do sistema escravista; e as marcas físicas das mesmas que guardava no seu corpo uma prova irrefutável que conferiu credibilidade ao seu depoimento, não deixando outra alternativa aos inquisidores, inicialmente cépticos, senão ilibá-la dos crimes de que se vira acusada.

1. Embora tratando-se de um depoimento indirecto, porque sujeito ao «filtro» do notário encarregue de registar as perguntas feitas pelos inquisidores no decurso dos interrogatórios e as respostas que lhes eram dadas pela ré, relatos como o de Luzia, com a sua qualidade informativa e a carga emocional de que, apesar de tudo, dão conta as palavras escritas, são, tanto quanto sabemos, pouco comuns, para o período colonial brasileiro. Os maus tratos directa ou indirectamente infligidos aos escravos pelos seus senhores eram, ao que tudo indica, frequentes' e a sua ocorrência inerente à exploração assente no domínio sobre os corpos e na submissão das vontades que se encontrava na base do sistema escravista, constituindo, portanto, um recurso indispensável ao seu próprio 1

\footnotetext{
Isso mesmo atestam as palavras de Filipe de Mendonça ou de Paredes, preso pela Inquisição em 1716 sob a acusação de judaísmo, que ao pretender negar ser filho de Luis de Paredes, um cristão-novo do Rio de Janeiro e aí senhor de engenho, disse que este o alforriara por sua morte devido aos bons serviços por si prestados e não porque fosse seu pai, "porquanto sempre o tratou como escravo; $e$ ainda pior do que a outros que tinha em caza Instituto dos Arquivos Nacionais/Torre do Tombo (daqui em diante, IAN/TT), Inquisição de Lisboa (IL), Proc. n. ${ }^{\circ} 11591$, fis. 24-v. Ao longo do nosso artigo, empregamos o conceito de «violência» na sua acepção mais estreita, i.e. como todo o constrangimento de ordem física ou psicológica susceptível de provocar medo e o sofrimento das suas vítimas. A violência sobre os escravos abarca, no entanto, um contexto mais vasto, ligado às privações e constrangimentos de vária ordem inerentes à sua própria condição. A este propósito, ver Didier Lahon, "Violência do Estado, violência privada. O verbo e o gesto no caso português", in Manolo Florentino \& Cacilda Machado (org.), Ensaios Sobre a Escravidão (I). Belo Horizonte: Editora UFMG, 2003:87-120; e "Penser la Violence. Perspectives philosophiques, historiques, psychologiques et sociologiques" (dossier temático). Revue Internationale des Sciences Sociales. Paris : UNESCO/érès, 132, mai. 1992.
} 
funcionamento e, mais do que isso, aceite como integrando a normalidade quotidiana, num tempo em que a violência permeava a vida corrente e os castigos corporais se achavam prescritos, como forma de punir legalmente os criminosos, nas normas sobre as quais se erguia o edifício da administração de justiça em Portugal e nos territórios sob o seu domínio².

A violência - física e psicológica - a que estavam sujeitos os cativos encontra-se, de facto, amplamente documentada nas obras dos autores que, no período por nós estudado, abordaram de forma sistemática a questão da escravidão e as suas particularidades na colónia portuguesa da América. Ao contrário do que se verificou em França, com a publicação do Code Noir (1685)3 ${ }^{3}$, nas colónias inglesas da América do Norte durante a primeira metade do séc. XVIII ${ }^{4}$, e em Espanha, onde a partir de 1768 foram promulgados códigos negros para as diferentes colónias, culminando na Real Cédula de 31 de Maio de 1789, "sobre la educación, trato, y ocupaciones de los esclavos, en todos sus dominios de Indias e Islas Filipinas "5, em Portugal não houve, tanto quanto se sabe, a preocupação de elaborar um corpo jurídico para a regulamentação das questões relacionadas com a escravidão. Referências aos cativos encontram-se, porém, dispersas em leis avulsas, publicadas ao longo de todo o período colonial. A julgar pelas mesmas, a grande preocupação da Coroa residia no controlo e regulamentação do tráfico; as fugas de escravos eram igualmente objecto de atenção, constituindo,

2 Sobre a questão da violência na Europa dos sécs. XV-XVIII e, de uma forma geral, no mundo moderno, existe hoje uma vasta bibliografia: v., p. ex., Alain Morvain (org.), Savoir et Violence en Angleterre du XVIe au XIXe Siècle: études. Lille: Université de Lille II, 1987; Julius Ruff, Violence in Early Modem Europe. Cambridge, etc.: Cambridge University Press, 2001; Natalie Zemon Davis, Society and Culture in Early Modem France: eight essays. Stanford, Califi: Stanford University Press, 1975; e Pieter Spierenburg (ed.), Men and Violence: gender, honor, and rituais in Modem Europe and America. Columbus: Ohio State University Press, 1998. Para uma visão sintética do assunto, v. José Andrés-Gallego, História da Gente Pouco Importante. Lisboa: Estampa, 1993, pp. 154-158,169-183 e 283-291 (orientações bibliográficas).

Sobre a evolução do Direito Penal e a alteração das práticas punitivas durante o séc. XVIII, v.: Douglas Hay, P. Linebaugh, C. Winslow, J. Rule, E. P. Thompson, Albion s Fatal Tree: crime and society in eighteenth-century England. Harmondsworth, etc.: Penguin, 1977; Michel Foucault, Surveiller et Punir: naissance de la prison. Paris : Gallimard, 1975; Pieter Spierenburg, The Spectacle of Suffering: executions and the évolution of repression. Cambridge, etc.: Cambridge University Press, 1984; e Randall McGowen, "The body and punishment in eighteenth-century England", Journal of Modem History, 59 (3), dez. 1987, pp. 651-679.

3 V, p. ex.: www.afcam.org/Doc_illustration/Code Noir/LECODENOIR.htm.

4 Alan Watson, Slave Law in the Américas. Athens: University of Georgia Press, 1989; Kenneth Morgan, Slavery and Servitude in Colonial America: a short history. Nova Iorque: New York University Press, 2000.

5 Manuel Lucena Salmoral, Los Códigos Negros de la América Española. Alcalá de Henares: Ed. UNESCO/Universidad de Alcalá, 1996. 
aliás, uma preocupação central para as autoridades coloniais; em terceiro lugar, apareciam questões como as do baptismo e enterro dos escravos, determinações a propósito do vestuário, especialmente no caso das mulheres, e aos ornamentos por elas usados, a proibição de mandar trabalhar os cativos ao Domingo e nos dias santos de guarda, e, entre outras, a dos castigos ${ }^{6}$.

Sob o ponto de vista legal, os escravos constituíam bens móveis, com um estatuto em quase tudo idêntico ao dos animais; eram passíveis de transacção comercial, à semelhança de qualquer outra mercadoria, e, uma vez comprados, ficavam à mercê dos proprietários, que podiam dispor deles como bem entendessem. Os senhores tinham, aliás, o direito de prender os seus escravos e de castigá-los para, dessa forma, os livrar de "más manhas e costumes "

Uns e outros, senhores e cativos, estavam, contudo, em última instância sujeitos à autoridade soberana do monarca, sendo certo que, no que a este dizia respeito, a preocupação central consistia em garantir o funcionamento do sistema assente na utilização da mão-de-obra escrava, indispensável para o desenvolvimento do Brasil segundo o modelo da exploração colonial, e a sobrevivência dos lucros provenientes do tráfico. A legislação sobre o transporte e venda dos escravos e, de uma forma geral, sobre a organização do comércio negreiro assumiu, deste modo, uma importância fundamental mas a Coroa também não podia ignorar os abusos praticados pelos senhores que, à revelia das autoridades e mostrando que, na prática, o destino dos seus escravos - incluindo a decisão de vida ou morte - dependia inteiramente da sua vontade ${ }^{8}$, os tratavam de forma violenta e por vezes mesmo desumana ${ }^{9}$.

6 Silvia H. Lara, Campos da Violência: escravos e senhores na Capitania do Rio de Janeiro, 1750-1808. Rio de Janeiro: Paz e Terra, 1988, pp. 34 e 37-38.

7 A expressão encontra-se nas Ordenações Filipinas, Liv. V, tít. XCV, § 4. ${ }^{\circ}$, que trata da proibição do cárcere privado: "Esta lei não haverá lugar no que encarcerar seu filho-famílias ou escravo, para os castigar e emendar de más manhas e costumes; porque em tal caso os poderá prender Extracto publicado por Silvia H. Lara, Legislação Sobre Escravos Africanos na América Portuguesa. Madrid: Fundación Histórica Tavera, 2000, p. 126. Este texto segue, aliás, de muito perto as disposições contidas nas Ordenações Manuelinas, Liv. V, tít. LXVIII, § $2 .^{\circ}$, sobre a mesma matéria: "Mas mandamos que esta lei não haja lugar naquele que encarcerar seu servo ou filho, para os castigar e emendar de más manhas e costumes que houverem; cá em tal caso os poderá cada um prender Ibidem, p. 73.

V. também, da mesma autora: "Do mouro cativo ao escravo negro: continuidade ou ruptura?", Anais do Museu Paulista, XXX, 1980/1981, pp. 375-398.

8 Santo Agostinho referiu-se a este aspecto, designou-o como a "tentação da libido dominandi", cf. Gervase Corcoran, OSA, Saint Augustine on Slavery. Roma, Institutum Patristicum «Augustinianum», 1985, p. 71.

9 Manolo Florentino e José Roberto Góes, A Paz das Senzalas. Famílias escravas e tráfico atlântico, Rio de Janeiro, c. 1790-c. 1850. Rio de Janeiro: Civilização Brasileira, 1997, p. 31, 
No plano político, o período da «monarquía corporativa», correspondente aos sécs. XVI e XVII, caracterizou-se pela dispersão da autoridade, com a existência de uma multiplicidade de focos periféricos de poder, em relação aos quais o rei assumia antes de mais o papel de um árbitro, cuja função consistia em garantir a manutenção da ordem estabelecida e dos equilíbrios que a sustentavam, em nome de uma hegemonia que, no dizer de António M. Espanha, seria apenas "simbólica Com o triunfo da «monarquia estatalista», a partir de meados do séc. XVIII, assistiu-se, porém, ao desenvolvimento de um projecto político que teria em última análise como objectivo "reduzir os pólos periféricos de poder, construir o Estado e fazer deste opólo único de disciplina social”. Sob o ponto de vista penal, o primeiro período caracterizar-se-ia assim pela afirmação ideológica do rei como origem última da justiça e, ao mesmo tempo, como fonte de clemência, numa ordem jurídica-penal não exactamente vocacionada para a punição efectiva dos faltosos e para o disciplinamento quotidiano da sociedade. No segundo período, o direito penal assumiria, contudo, uma intenção prática mais evidente, convertendo-se num mecanismo essencial para a normalização e disciplina dos indivíduos e dos grupos aos quais pertenciam ${ }^{10} 11$.

Baltazar da Silva Lisboa, nos Annaes do Rio de Janeiro, menciona uma carta régia, dirigida ao governador daquela Capitania, em cumprimento da qual os senhores cujos excessos fossem do conhecimento público, seriam obrigados a vender os escravos sobre quem recaíam os maus tratos, com a condição de o fazerem a quem deles bem cuidasse. O documento, cujo texto se perdeu, foi emitido em 20 de Julho de 1642 mas, ao que parece, não chegou a entrar em vigor ${ }^{11}$, provavelmente devido à oposição dos proprietários. Uma nova ordem, emitida em 1688, determinava que, durante as devassas gerais levadas a efeito no Rio de Janeiro, se inquirisse "pelos senhores que com crueldade [castigassem] os seos escravos, e que aquelles que o [fizessem fossem] obrigados a vende lios a pessoas que lhe [dessem] bom tratoeque, havendo quem [denunciasse] perante as Justiças

assinalam que a regulamentação feita por intermédio da lei, quanto ao "uso " do escravo, constituía um procedimento semelhante ao que era adoptado relativamente a "outros tipos de propriedade", sendo disso um exemplo a proibição de castigos cruéis. A própria legislação reconhecia, no entanto, a "natureza especial" deste bem, porque, ao punir os crimes por si praticados, "reconhecia humanidade no escravo", uma vez que, como referem os autores, "nenhuma outra propriedade épunível ". Para Jacob Gorender (O Escravismo Colonial. São Paulo: Ática, 1978, p. 65, citada no texto), o crime seria assim "o primeiro acto humano do escravo".

10 António M. Hespanha, "Da «Iustitia» à «Disciplina». Textos, poder e política penal no Antigo Regime", in António M. Hespanha (org.), Justiça e Litigiosidade: História eprospectiva. Lisboa: Fundação Calouste Gulbenkian, 1993, pp. 287-379. Do mesmo autor, v. também "Centro e periferia no sistema político português do Antigo Regime”, Ler História, 8, 1986, pp. 65-84.

${ }^{11}$ Cf. Silvia H. Lara, Legislação Sobre Escravos..., p. 167. 
dos senhores [...] se lhes [tomassem] as denunciaçoens, ou querellas, e ainda as que [dessem] os mesmos escravos castigados Como justificação para estas medidas, aludia-se ao facto de cá ter chegado a notícia que "muitos dos moradores" daquelas partes davam "muito mao trato" aos escravos de que eram possuidores e os castigavam "com crueldade", o que, dizia-se, "não [hera] licito aos senhores dos taes escravos porque so lhe [podiam] dar aquelle moderado castigo que [hera] permitido pelas leys "n. Esta carta foi seguida por uma outra, emitida apenas alguns dias mais tarde, na qual se referia novamente o último aspecto, afirmando-se que alguns dos moradores "[excediam] aquela moderação que [héra] permetida aos senhores quando [castigavão] aos escravos no que não sómente [obravão] contra aprohibição das leys, mas tãobem contra a charidade dos proximos". O governador devia, pois, recolher informações sumárias (de carácter verbal) acerca da forma como eram tratados os escravos e punir os senhores que se verificasse estarem naquelas condições, castigando-os segundo o seu próprio arbítrio; os casos mais graves seriam remetidos ao ouvidor geral para serem julgados; e, além de outras penas, os senhores que corrigissem os seus escravos com mais dureza do que lhes era permitido deveriam ser obrigados a vendê-los, sendo que o novo proprietário teria que os tratar "com castigo moderado "n. Em 23 de Fevereiro do ano seguinte, estas duas cartas seriam, contudo, revogadas, após a recepção de uma outra, enviada pelo governador geral do Brasil [Matias da Cunha], em que dava conta dos "grandes inconvenientes " que resultariam da sua execução, aludindo às "perturbaçoens " que, a pretexto do que nelas se determinara, haviam já começado a verificar-se na relação dos escravos com os seus senhores ${ }^{12} 1314$. No entanto, esta carta seria, também ela, revogada um ano mais tarde, altura em que terão reentrado em vigor as ordens expedidas em $1688^{15}$.

12 Carta régia ao governador do Rio de Janeiro (Lisboa, 20 de Março). Arquivo Nacional do Rio de Janeiro (daqui em diante ANRJ), Secção de Documentos Históricos, Registo de Cartas Régias, Códice 63, vol. 1 (1662-1724), fis. 37v.-38. V. também Silvia H. Lara, Legislação Sobre Escravos..., p. 198.

13 Carta régia ao governador do Rio de Janeiro (Lisboa, 23 de Março). ANRJ, Secção de Documentos Históricos, Registo de Cartas Régias, Códice 63, vol. 3 (1662-1741), fis. 54-v. V. também Silvia H. Lara, Legislação Sobre Escravos..., p. 199.

14 Carta régia ao governador do Rio de Janeiro, D. Francisco Naper de Lencastre (cuja posse teria lugar em Junho) (Lisboa, 23 de Fevereiro de 1689). ANRJ, Secção de Documentos Históricos, Registo de Cartas Régias, Códice 63, vol. 1, fis., 47v.-48. A missiva enviada, no ano anterior, da Baía pelo governador geral (entretanto falecido), tinha a data de 11 de Agosto. Silvia H. Lara, Legislação Sobre Escravos..., p. 201.

15 Por carta régia de 11 de Janeiro de 1690, cf. Agostinho Marques Perdigão Malheiro (A Escravidão no Brasil. Ensaio Histórico-Jurídico-Social, 1 . edição: 1866), citado por Silvia H. Lara, Legislação Sobre Escravos..., p. 45 (nota 140). O documento a que Perdigão Malheiro 
Nos anos seguintes, foi publicada ainda mais alguma legislação a favor dos escravos: em 1693, proibiu-se que os encarcerados por crimes leves ou a requerimento dos próprios senhores fossem colocados a ferros ou "metidos em prisões mais apertadas que aquelas que [bastassem] para a segurança "16; em 7 de Fevereiro de 1698, o governador do Rio de Janeiro recebeu ordens para impedir que os senhores prendessem os seus escravos com argolas de ferro, tendo em vista o castigo dos mesmos, por se tratar de um procedimento que, embora comum, era "inhumano" e ofendia "a natureza e as leys "17; finalmente, por carta régia de 5 de Novembro de 1710, determinava-se que o procurador da Coroa (que também o era da Fazenda) naquela Capitania actuasse como juiz privativo dos escravos, nas causas por estes movidas aos seus senhores, com a assistência de um solicitador nomeado pelo governador, a quem se recomendava cuidado em examinar se continuava "o mau trato nos escravos" e que por todos os modos o procurasse

faz alusão não pôde ser localizado mas a Autora menciona duas ordens que parecem confirmar a informação por si veiculada: a primeira, de 1702, mandava julgar sumariamente na Relação da Baía um senhor que fora acusado de crueldade por uma escrava da qual era proprietário; a segunda é uma carta régia de $\mathbf{1 7 0 6}$, dirigida ao ouvidor geral daquela cidade, pela qual se mandava proceder contra um senhor, igualmente acusado por uma das suas escravas de a tratar com rigor e que, por isso, queria libertar-se da sua posse (Ibidem, p. 201 : nota 309). Na Torre do Tombo, encontrámos, porém, uma carta régia de 11 de Janeiro de 1690, dirigida ao arcebispo D. Fr. Manuel da Ressurreição, que ocupava interinamente o cargo de governador, cujo teor é o seguinte: "Mandei ver a devassa que pello chancélher dessa Relação se tirou e a queixa, que me fez Ursulla escrava do reyno de Congo de sua patroua D. Anna Cavalcanti; e [fl. 56 v.J porque delia não conste das sevicias, e crueldades com que he tratada, antes o contrario, por sua mesma confissão, em que as palavras da suplica forão acresentadas sem seu consentimento, $e$ contra a verdade do facto, porém, porque se presume que a dita sua patroua se tiver vencimento na cauza que tráz na Ouvedoria Geral do Civel, sobre o pleito da liberdade, poderá continuar com mais aspereza, e fazer que a culpa seja mais verdadeira, que afectada, e a penna de obrigar os senhores a que vendão os escravos, quando justamente temem á aspereza do castigo he $<a>$ que o direito premitte; hey por bem que ella seja obrigada a vende lia pello justo preço em que for avaliada de que vos mando avizar para que assim o façais executar”. IAN/TT, Papéis do Brasil, Avulsos, mç. 2, n. ${ }^{\circ}$ 2, fis. 56-v. Será este o documento a que se refere Perdigão Malheiro?

16 Decreto de 30 de Setembro (ou 16 de Novembro) de 1693. Silvia H. Lara, Legislação Sobre Escravos..., p. 206.

17 Carta régia a Martim Correia Vasques que, na ausência do governador Artur de Sá e Meneses, exercia interinamente o governo da Capitania. ANRJ, Secção de Documentos Históricos, Registo de Cartas Régias, Códice 63, vol. 1, fis. 111 - v. V. também Silvia H. Lara, Legislação Sobre Escravos..., p. 211. Jorge Benci, SJ, "Economia christãa dos senhores no governo dos escravos. [...] pelo padre Jorge Benci de Arimino da Companhia de Jesu, missionário da Provincia do Brasil. [...] Em Roma, na officina de Antonio de Rossi na Praça de Ceri. 1705”, pp. 172-173, transcreve uma outra carta, em tudo semelhante a esta, que informa ter sido enviada a D. João de Lencastre, governador e capitão-general do Estado do Brasil. 
evitar, "de maneira que [cessasse] o clamor que [sentiam] estes mizeraveis nesta parte" 18 .

Os maus tratos infligidos aos escravos pelos seus senhores constituíam um factor permanente de instabilidade que, ao fomentar a revolta dos cativos, não só ameaçava pôr em causa a ordem instituída, como a própria sobrevivência da colónia e a sua exploração nos termos definidos pela metrópole. Na perspectiva dos senhores, o castigo era, porém, um instrumento essencial de dominação, que lhes permitia ao mesmo tempo punir os faltosos, reprimir os ímpetos dos escravos e desencorajar a insubordinação, mediante o recurso a penas exemplares; a violência - efectiva ou meramente sugerida, como uma ameaça permanente, que a qualquer momento poderia concretizar-se - funcionava pois como um mecanismo de afirmação de poder por parte dos senhores, promovendo a criação de uma mão-de-obra disciplinada e submissa, o controlo dos cativos e a aceitação pelos mesmos da sua própria condição.

A Coroa enfrentava deste modo um dilema: se, por um lado, não era possível negar aos senhores o direito de punir os seus escravos, sob pena de enfraquecer a autoridade dos mesmos e promover a criação de desequilíbrios que poriam em causa a própria ordem colonial ${ }^{19}$, por outro lado, o monarca não podia também permitir que alguns entre os seus vassalos - ainda mais se, como era o caso, residiam longe do centro de poder - se arvorassem em senhores absolutos, agindo guiados unicamente pelo seu arbítrio, em manifestações abusivas de força que ofendiam a autoridade suprema do rei, motivo pelo qual era imperioso garantir o controlo dos proprietários coloniais e a submissão dos mesmos aos ditames emanados da metrópole. Exercendo uma função "essencialmente jurisdicional " que limitava a sua actuação, impedindo-o de colidir com os direitos de particulares, e não dispondo dos mecanismos indispensáveis à efectivação da sua vontade, o rei procurava conquistar a obediência dos súbditos com o recurso a meios não violentos, gerindo os conflitos de forma a permitir a criação de consensos e a manutenção da ordem instituída. Ao invés de punir, ameaçava e só em

18 Carta régia ao governador Francisco de Castro Morais. ANRJ, Secção de Documentos Históricos, Registo de Cartas Régias, Códice 63, vol. 1, fis. 228-v. Publicada por Silvia H. Lara, Legislação Sobre Escravos..., pp. 232-233.

$19 \mathrm{Na}$ verdade, a Coroa dependia mesmo, em grande medida, dos senhores para evitar a insubordinação dos cativos, porque, como assinala Silvia H. Lara (Campos da Violência..., p. 41), embora tivesse todo o interesse em garantir a manutenção do sistema escravista na sua colónia da América, "não dispunha, porém, de recursos para o controle da massa escrava nem de meios para efetivá-lo internamente à unidade de produção", pelo que tinha que confiar nos senhores para o fazerem. 
última instância fazia sentir o peso da sua autoridade sobre quem persistisse em desobedecer-lhe ${ }^{20}$.

Os avanços e recuos de que acima demos conta, no que se refere à punição dos senhores acusados de abusos para com os seus escravos, enquadram-se, portanto, de maneira exemplar na forma de exercício do poder régio característica dos sécs. XVI e XVII. Procurando conciliar os direitos dos senhores com a necessidade de garantir a manutenção da paz, indispensável ao funcionamento do sistema colonial, e o respeito pela sua própria autoridade, o rei apoiava-se nos valores cristãos da caridade para apelar ao castigo moderado dos escravos, cuja condição não era, porém, sequer questionada. $\mathrm{Na}$ carta de 23 de Março de 1688 a que atrás fizemos menção, as autoridades a quem ela se dirigia - o governador do Rio de Janeiro era um dos destinatários - recebiam indicações explícitas para punir os faltosos, tendo porém o cuidado de evitar "quanto vos for posivel que chegue a noticia dos escravos este remedio que se dá ao seo immoderado castigo, por se evitar que com menos justificada cauza poderão arguir a seos senhores, e se entender que bastará que os senhores saibão a forma em que mando proceder contra elles" 21 . Os "inconvenientes" que da sua execução resultariam para o serviço real e para a conservação do Estado do Brasil, foram as razões invocadas no ano seguinte para revogar as medidas anteriormente publicadas; o documento, a que também já nos referimos, acrescentava ainda que, julgando-se necessário, os escravos deveriam ser informados da resolução tomada, "para que se evitem as perturbaçoens que entre elles e seos senhores ja começava a haver, com a noticia das ordens que se vos havião passado"22. A “charidade dos proximos", referida na carta de $1688^{23}$, e o carácter degradante dos castigos, que constituíam uma ofensa às leis humanas e naturais, justificaram a proibição do uso de argolas de ferro para prender os escravos, segundo a carta nesse sentido enviada ao governador do Rio de Janeiro em 1698. Ao mesmo tempo, recomendava-se-lhe porém o uso de meios "prudentes e efficazes", a fim de evitar tanto o "alvoroço nos povos" como o "ruido ou

20 António M. Hespanha, "Da «Iustitia» à «Disciplina»..., pp. 297-320. Nesta obra, veja-se também, do mesmo autor, "Justiça e Administração entre o Antigo Regime e a revolução", pp. 381-468.

21 ANRJ, Secção de Documentos Históricos, Registo de Cartas Régias, Códice 63, vol. 3, fl. 54.

22 ANRJ, Secção de Documentos Históricos, Registo de Cartas Régias, Códice 63, vol. 1, fl. 48.

23 ANRJ, Secção de Documentos Históricos, Registo de Cartas Régias, Códice 63, vol. 3, fl. 54. Na carta de 5 de Novembro de 1710, atrás mencionada, insistia-se neste ponto ao fazer-se referência aos senhores que "sem piedade nem temor de Deos " castigavam rigorosamente os seus escravos. ANRJ, Secção de Documentos Históricos, Registo de Cartas Régias, Códice 63, vol. 1,fl. 228 . 
alteração dos mesmos escravos "24. A moderação era, em suma, a chave do dilema e o meio através do qual se pretendia assegurar a manutenção de um equilíbrio - ainda que precário - na relação senhor-escravo ${ }^{25}$.

Ao longo do séc. XVIII, haveria ainda outras iniciativas legislativas destinadas a impor o comedimento na punição dos cativos: a insistência neste ponto indica, por outro lado, que a legislação era frequentemente ignorada pelos senhores, num claro desafio à autoridade metropolitana, possível graças às limitações a que acima fizemos referência na implementação da autoridade régia e à existência de solidariedades fotjadas localmente. Em 1714, o governador-geral do Brasil recebeu de facto indicações para garantir que fosse infalivelmente executada "a ordem" de 1688, porque havia chegado a Lisboa a informação que "se não [observava], antes a dissimulação de se executar [tinha] facilitado o uso dos ditos senhores de escravos usarem com eles de castigos tiranos", o que deveria a todo o custo evitar-se para não dar ocasião às queixas dos mesmos escravos $^{26}$. Segundo Perdigão Malheiro, as cartas de 1688 teriam sido mais uma vez restauradas em 20 de Novembro de $1779^{27}$ mas, ao mesmo tempo em que se tomavam medidas para proteger os escravos da violência a que estavam sujeitos por parte dos senhores, os fugitivos eram também severamente punidos: por alvará de 3 de Março de 1741, determinava-se, com efeito, a «marcação» dos negros capturados nos ataques a quilombos ${ }^{28}$ que para aí se tivessem deslocado

24 ANRJ, Secção de Documentos Históricos, Registo de Cartas Régias, Códice 63, vol. 1, fis. 111 -v. Na transcrição de Silvia H. Lara (Legislação Sobres Escravos..., p. 211), a palavra "donos" aparece no lugar de "povos".

25 Idem, Campos da Violência..., pp. 65-69 e 82-96.

26 Carta régia de 17 de Janeiro de 1714 (Lisboa). Idem, Legislação Sobre Escravos..., p. 237.

27 Ibidem, p. 45 (nota 140). Alguns dias mais tarde, a 27 de Novembro, a Irmandade de S. Benedito afecta ao convento de S. Francisco de Lisboa recebia permissão para resgatar os escravos que fossem vítimas de maus tratos ou que estivessem em risco de ser vendidos para fora do Reino. Idem, Campos da Violência..., pp. 67-68.

28 O Dicionário Houaiss da Língua Portuguesa (Edição electrónica: Instituto Antônio Houaiss-Editora Objetiva, 2001) assinala para a palavra «quilombo» entre outras as seguintes designações: "2Rubrica: história. Regionalismo: Brasil, local escondido, ger. no mato, onde se abrigavam escravos fugidos; 3Rubrica: história. Regionalismo: Brasil, povoação fortificada de negros fugidos do cativeiro, dotada de divisões e organização interna (onde tb. se acoitavam índios e eventualmente brancos socialmente desprivilegiados)". Numa carta de 6 de Março de 1741, enviada por intermédio do Conselho Ultramarino a Gomes Freire de Andrade, governador e capitão-general do Rio de Janeiro, definia-se «quilombo» como sendo "toda a habitação de negros fugidos que passem de sinco em parte despovoada, ainda que não tenhão ranchos levantados, nem nelles se achem piloens ANRJ, Secção de Documentos Históricos, Registo de Cartas Régias, Códice 63, vol. 2, fl. 104v. 
voluntariamente, pondo-se-lhes "com fago hua marca em hua espadua com a letra $F$ "; aos reincidentes, seria cortada uma orelha ${ }^{29}$.

Com o triunfo do despotismo, o monarca viu a sua preeminência reforçada, a máquina do Estado modemizou-se, ganhando eficiência e um alcance abrangente, cada vez mais tentacular, e os poderes periféricos perderam autonomia de actuação, ao mesmo tempo que a sua capacidade de influência ia sendo progressivamente reduzida. A mediação entre grupos com interesses distintos, tendo em vista a formação de consensos, deu lugar à imposição de uma disciplina única, reguladora da vida social, como parte do projecto político de expansão do poder da Coroa. No plano jurídico-penal, registaram-se assim alterações significativas: a punição, que anteriormente cumpria uma função acima de tudo simbólica, adquiriu uma dimensão eminentemente prática, em que a lei funcionava como um mecanismo real de defesa da ordem estabelecida, assegurando o controlo dos comportamentos e o castigo dos elementos desviantes. As transformações sofridas pelo discurso jurídico e a sua intenção, agora claramente definida no sentido de intervir efectivamente na ordenação da realidade, deram, além disso, origem a novas questões, como a do humanitarismo, directamente relacionadas com o novo papel do Direito na sociedade portuguesa da segunda metade do séc. XVIII e com a difusão das ideias iluministas no nosso país ${ }^{30}$.

Ao analisar o período em questão, António M. Espanha assinalou porém quea " 'prática punitiva real', continuaria a ser prejudicada por "limitações estruturais" de vária ordem ${ }^{31}$. No que se refere à matéria de que aqui tratamos - os maus tratos de natureza física infligidos pelos senhores aos seus escravos - havia ainda factores adicionais que contribuíam de forma decisiva para dificultar o exercício de um controlo efectivo por parte das autoridades: um deles era a distância à metrópole, agravada pelo jogo dos interesses particulares, pela existência de redes de poder a funcionar localmente e de clientelas instaladas e, sobretudo, pelo isolamento dos escravos nos engenhos e, de um modo genérico, nas fazendas situadas quase sempre em lugares afastados dos aglomerados populacionais, onde viviam teoricamente privados de mobilidade e na prática com poucas possibilidades de iludir a apertada fiscalização a que se encontravam sujeitos ${ }^{32}$.

29 ANRJ, Secção de Documentos Históricos, Registo de Cartas Régias, Códice 63, vol. 2 (1725-1777), fis. 103-v. Publicado por Silvia H. Lara, Legislação Sobre Escravos..., p. 297.

30 António M. Hespanha, “Da «Iustitia» à «Disciplina»”..., pp. 293-294 e 321-327.

31 Ibidem, p. 321.

32 A literatura clássica sobre a escravidão atribui, regra geral, um papel meramente passivo aos escravos, sugerindo mais ou menos explícitamente que, sobretudo os que viviam no meio rural, não tinham qualquer tipo de mobilidade. Os estudos levados a cabo nos últimos anos vieram porém alterar esta e outras ideias até aí largamente aceites, chamando a atenção para as 
Além disso, se os escravos representavam um investimento que à partida deveria ser preservado, também é, quanto a nós, evidente que os senhores dificilmente poderiam abrir mão do castigo, dado que, tanto sob o ponto de vista prático como simbólico, este desempenhava um papel fundamental enquanto instrumento de submissão dos cativos, exibindo, muitas vezes de forma brutal, a preeminência dos senhores e o vigor do seu domínio ${ }^{33}$. Estas são, em suma, algumas das razões ${ }^{34}$ que explicam o, ao que tudo indica, escasso número de

estratégias de que os escravos se socorriam para iludir/resistir à servidão e, entre outros aspectos, para as suas movimentações, que muitas vezes assumiam a forma de fugas de curta duração e "escapadelas" ocasionais ( "petit marronage ", segundo a expressão consagrada na historiografia). As fontes testemunham, de facto, abundantemente que, pesem embora as restrições óbvias a que pela sua própria condição estavam sujeitos, os escravos não permaneciam indefinidamente no mesmo lugar: acompanhavam os senhores nas suas deslocações, passavam de mãos, fugiam e, entre muitos outros incidentes que podiam alterar o curso das suas vidas, os que, por exemplo, tivessem o infortúnio de ser presos por ordem da Inquisição eram enviados para Lisboa. Sobre este assunto, ver Richard Price (ed.), Maroon Societies: rebel slave communities in the Américas. Baltimore: Johns Hopkins University Press, 1996 (3a), e a bibliografia aí indicada; para o caso brasileiro, vejam-se, além de diversas obras recentes, os estudos pioneiros de José Alípio Goulart, Da Fuga ao Suicídio: aspectos de rebeldia dos escravos no Brasil Rio de Janeiro: Conquista/ INL, 1972; Clóvis Moura, Rebeliões da Senzala. Quilombos, insurreições e guerrilhas. Rio de Janeiro: Conquista/INL, 1972; e Stuart B. Schwartz, "Résistance and accommodation in Eighteenth-Century Brazil". Hispanic American Historical Review, n. ${ }^{\circ}$ 57, 1977: 69-81; bem como João José Reis e Eduardo Silva (org.), Negociação e Conflito: a resistência negra no Brasil escravista. São Paulo: Companhia das Letras, 1989.

33 A visão empresarial do escravismo, em que os senhores actuariam movidos por uma 'férrea racionalidade económica ", segundo a lógica do capitalismo, tem vindo aliás a ser questionada por diversos autores: Manolo Florentino e José Roberto Góes (Ob. cit., pp. 28-31) assinalam, a propósito, que, embora seja certo que o senhor de escravos "tendia a adotar um cálculo económico “moderno ”, já que se achava preso a uma engrenagem económica ampla sobre a qual exercia desprezível influência ", um e outro, senhor de escravos e empresário capitalista, representavam sociedades "portadoras de racionalidades distintas ", já que este não obtinha os seus lucros mediante a "coerção extra-económica" mas aquele forçava os seus escravos a trabalhar. De facto, “o "cálculo" senhorial não podia ser estritamente económico, talvez sequer pudesse sê-lo predominantemente. Dos escravos, por definição, não se esperava que trabalhassem por se os haver furtado dos meios de subsistência e, mesmo, do direito sobre o seu corpo: se lhes obrigava. As estratégias senhoriais deveriam ser, antes de mais nada, políticas ".

34 Outras mais poderiam ser mencionadas como, por exemplo, a de que os grandes interessados em que os senhores respondessem perante a Justiça eram obviamente as vítimas, isto é: os próprios escravos. Ora, a ignorância (sobretudo no caso dos recém-chegados), a falta de posses e a indiferença por parte dos agentes encarregues da implementação da autoridade, assim como o medo de represálias, eram outros tantos obstáculos que dificultavam o seu acesso à Justiça. Esse foi, de resto, o motivo invocado para justificar a nomeação de um juiz privativo para os escravos na Capitania do Rio de Janeiro, cf. ANRJ, Secção de Documentos Históricos, Registo de Cartas Régias, Códice 63, vol. 1, fl. 228. 
processos que, mesmo durante o séc. XVIII, tiveram como alvo proprietários de escravos, em razão dos maus tratos sobre eles infligidos. Num estudo já clássico sobre as relações senhor-escravo em Campos dos Goitacazes, uma vasta região rural na periferia do Rio de Janeiro, Silvia H. Lara afirma, na verdade, que "ainda que tenhamos conhecimento de muitas querelas entre senhores $e$ cativos relativas à compra de liberdade ou alforria, poucos são os documentos deste tipo que tratam de sevícias”. A justificá-lo, adianta que entre todos os processos por si consultados - cerca de duas centenas, para o período compreendido entre 1750 e 1808 - apenas um foi instituído específicamente para averiguar uma matéria desta natureza, não obstante o facto de em muitos deles se encontrarem referências a "castigos severos e cruéis", 35 .

2. Ao longo da época moderna, o Direito e a Justiça adquiriram um papel cada vez mais preponderante entre as chamadas "tecnologias disciplinares ", tomando-se progressivamente fundamentais enquanto mecanismo de realização do controlo social por parte do Estado, que chamava a si o monopólio da violência, punindo como ilegais os castigos não decretados por sentença e os actos privados de vingança ${ }^{36}$.

Antes da segunda metade do séc. XVIII, o Estado não tinha, contudo, à sua disposição os meios necessários para garantir a implementação efectiva da sua autoridade. A estabilidade social repousava assim, em grande medida, sobre "mecanismos de constrangimento situados num plano diferente do da ordem penal real". O mesmo é dizer que, até ao advento do despotismo, o controlo dos comportamentos dependia em primeiro lugar da família, da acção levada a cabo pela comunidade e, em não pequena parte, do posicionamento assumido pela Igreja ${ }^{37}$, uma instituição sólidamente estabelecida que, pelo seu papel de intermediária na relação entre os homens e o divino, era temida e respeitada e, por isso mesmo, detinha um enorme poder de persuasão e uma influência inegável, tanto no que se referia à condução da vida dos fiéis, como até na articulação dos discursos oficiais.

Ciente de que a instituição eclesiástica possuía uma organização superior à do próprio Estado e uma capacidade de penetração invejável, que se traduzia na sua presença (mais ou menos significativa, é certo) em todos os espaços do império, a Coroa não hesitava em recorrer ao auxílio da Igreja para a prossecução dos seus próprios fins. No documento de 23 de Março de 1688, a que atrás nos

\footnotetext{
35 Silvia H. Lara, Campos da Violência..., p. 69-70.

36 António M. Hespanha, "Justiça e administração...”, p. 411.

37 Idem, “Da «Disciplina» à «Iustitia»...”, p. 317.
} 
referimos, o governador do Rio de Janeiro era assim instruído, além do mais que se lhe dizia, nos seguintes termos: "e fazendo vos a saber o bispo [D. José de Barros Alarcão] que [fl. 54v.] lhe consta que algum senhor castiga aos seos escravos com crueldade, e tirania, procedereis contra elle na forma referida porque aos prelados ordeno que quando lhe constar de semelhante excesso mandem dar parte aos governadores "38. Se esta ordem foi ou não cumprida pelos dois prelados que então dirigiam a igreja na colónia - um, o arcebispo da Baía, e o outro responsável pelo Bispado do Rio de Janeiro, criado havia poucos anos, em 1676 - não o sabemos mas na carta escrita ao governador desta capitania, em 5 de Novembro de 1710, dizia-se claramente que a decisão de nomear um juiz privativo para os escravos fora motivada por uma representação do bispo D. Fr. Francisco de São Jerónimo ${ }^{39}$, na qual dava conta da "vexação que [padeciam] os escravos [da capitania] com o rigor do castigo que lhes [davam] seos senhores sem piedade nem temor de Deos obrigando os com o medo delle a meterem se pelo certão por não terem posses nem possibilidade para requererem perante o seo juiz privativo a mudança de cativeiro, sendo isto cauza de se lhes faltar com a justiça "40.

A questão dos maus tratos sobre os cativos está intrinsecamente relacionada com a discussão sobre o carácter da escravidão no Brasil e, de um modo geral, nas Américas que, durante muito tempo, alimentou o debate historiográfico, dentro e fora do país ${ }^{41}$. Os contrangimentos de natureza física e psicológica

38 ANRJ, Secção de Documentos Históricos, Registo de Cartas Régias, Códice 63, vol. 3, fis. 54-v.

39 Cónego secular de S. João Evangelista, foi nomeado em 10 de Dezembro de 1700, chegou ao Rio de Janeiro em 8 de Junho de 1702 e ali permaneceu até à sua morte em 7 de Março de 1721. Foi o segundo bispo com residência na capital fluminense, sucedendo a D. José de Barros Alarcão, chegado em 1680 (D. Fr. Manuel Pereira, nomeado em 1676, não chegou a tomar posse do cargo).

40 ANRJ, Secção de Documentos Históricos, Registo de Cartas Régias, Códice 63, vol. 1, fl. 228.

41 Para uma análise sintética deste debate, ver: Ronaldo Vainfas, Ideologia \& Escravidão. Os letrados e a sociedade escravista no Brasil Colonial. Petrópolis: Vozes, 1986, pp. 14-21; e Silvia H. Lara, Campos da Violência..., pp. 97-113, cuja abordagem seguimos de mais perto. Embora as duas aproximações sejam no fundo coincidentes, completando-se mutuamente, Ronaldo Vainfas propõe contudo uma interpretação ligeiramente diferente da que é apresentada por Silvia H. Lara, destacando numa primeira fase, correspondente ao período dominado por Gilberto Freyre, a construção das imagens do senhor "bondoso " e do escravo "dócil e submisso a crítica a esta posição pela valorização da "rebeldia " negra e pela inversão do modelo anteriormente proposto, com a criação da imagem do senhor "cruel ", nas décadas de 1950-60; e numa terceira fase, com Florestan Femandes e o seu grupo, a atenção quanto à possibilidade de articulação entre paternalismo e violência na relação escravista e a reflexão sobre o papel do racismo na evolução da sociedade brasileira. 
inerentes ao funcionamento do escravismo, a iniquidade de um sistema baseado na apropriação do homem pelo homem, a violência implícita à deslocação forçada de milhares de indivíduos, arrancados ao seu meio de origem, privados de direitos e explorados como mão-de-obra escrava nas fazendas do Novo Mundo, são inegáveis e como tal reconhecidos pela generalidade dos autores. No entanto, a publicação de Casa Grande \& Senzala, ocorrida em 1933, inaugurou uma polémica que, durante várias décadas, iria dividir opiniões, com os herdeiros de Gilberto Freyre a defenderem uma concepção paternalista, segundo a qual as relações entre senhores e escravos no Brasil se teriam caracterizado pela convivência harmoniosa, por uma confraternização não violenta e, muitas vezes, quase familiar, que viria a traduzir-se num elevado grau de miscigenação entre os elementos de origem europeia e africana e no advento do mulato, como síntese feliz entre duas culturas mutuamente enriquecedoras e expressão máxima da democracia racial brasileira ${ }^{42}$. A esta corrente, opuseram-se, sobretudo a partir do início da década de 60, vários autores para quem o sistema escravista assentava antes de mais no exercício da violência sobre os escravos, dela dependendo para se manter, e que, por isso, contestavam a visão segundo a qual os escravos teriam beneficiado de condições mais favoráveis no Brasil do que noutras regiões do continente americano, denunciando-a como idílica e evidenciando - por vezes de forma exagerada - a crueldade inerente àquele regime de exploração do trabalho, bem como a opressão a que se encontravam sujeitos os cativos, cuja capacidade de resistência era agora enaltecida, contrariando a imagem do escravo dócil e passivo anteriormente proposta ${ }^{43}$.

${ }^{42}$ Gilberto Freyre, [ 1933] Casa Grande \& Senzala. Formação da família brasileira sob o regime de economia patriarcal Lisboa: Ed. «Livros do Brasil», 1957 (ed. port.). Entre os seus discípulos mais destacados, contam-se Frank Tannenbaum, Slave and Citizen. The Negro in the Américas. Nova Iorque: Knopf, 1947; Stanley M. Helkins, Slavery. A problem in American institutional and intellectual life. Chicago: The University of Chicago Press, 1959; e Herbert S. Klein, Slavery in the Américas. A comparative study of Cuba and Virginia. Chicago: The University of Chicago Press, 1967. Para uma discussão do pensamento de Gilberto Freyre e da herança «freyreana» no nosso país, ver Adriano Moreira e José Carlos Venâncio (org.), Luso-Tropicalismo. Uma teoria social em questão. Lisboa: Vega, 2000.

43 Ver, por exemplo: Fernando Henrique Cardoso, Capitalismo e Escravidão no Brasil Meridional. São Paulo: Difel, 1962; Octavio Ianni, As Metamorfoses do Escravo. São Paulo: Difel, 1962; Charles R. Boxer, Race Relations in the Portuguese Colonial Empire (1415-1825). Londres: Oxford University Press, 1963; e Emilia Viotti da Costa, Da Senzala à Colónia. São Paulo: Difel, 1966. Sobre o tema da rebelião escrava, ver: Décio Freitas, Palmares, a guerra dos escravos. Rio de Janeiro: Graal, $1978\left(2^{\mathrm{a}}\right)$; as duas obras atrás referidas de Clóvis Moura e José Alípio Goulart e, deste último, sobre a violência de que eram vítimas os escravos: Da Palmatória ao Patíbulo (castigos de escravos no Brasil). Rio de Janeiro: Conquista/INL, 1971. 
A partir dos anos 70, surgiram contudo novas propostas de abordagem, que pretendían! eliminar ou mesmo superar a oposição entre paternalismo e violência, sugerindo que as relações sociais no interior do sistema escravista eram matizadas e muito mais complexas do que até aí se julgara, nelas intervindo uma multiplicidade de factores que, em momentos distintos, determinavam comportamentos diferenciados. A introdução de novas variáveis, com a deslocação do debate do tratamento que era dado aos escravos para a análise dos mecanismos de controlo e dos recursos utilizados pelos grupos dirigentes para assegurar a manutenção e perpetuação do sistema escravista, permitiu reequacionar a questão, relançando o debate em moldes distintos daqueles em que ele até aí se produzira. Dos contributos - aliás nem sempre coincidentes - de diversos autores, emergiu progressivamente a noção de que o paternalismo e a violência eram duas faces de uma mesma realidade, conjugando-se no seio de uma relação caracterizada pela integração de elementos contraditórios e pela procura de equilíbrios, constantemente restabelecidos, em que a coerção e a persuasão se articulavam de modo a garantir a submissão dos cativos, tendo em vista a maximização do lucro ${ }^{44}$.

O princípio segundo o qual a relação senhor-escravo era determinada pela existência de obrigações recíprocas, que deviam ser cumpridas por ambas as partes de modo a garantir o funcionamento «harmonioso» do sistema, encontrava-se já, de resto, presente nas obras - escassas - dos autores que, durante o período colonial, se detiveram na análise da escravidão, tal como lhes era dado observá-la no Brasil. Na verdade, a permanência de um regime económico assente na exploração de mão-de-obra escrava não foi posta em causa por aqueles autores, do mesmo modo que não se questionava o direito da redução ao cativeiro. Pelo contrário, ao justificarem a privação de liberdade pelo recurso a argumentos de natureza religiosa, ligados à salvação dos cativos por intermédio da adesão ao Cristianismo, à desvalorização dos padecimentos sofridos na Terra mediante a perspectiva da vida eterna e até a uma alegada predestinação dos negros para a servidão inscrita na própria Bíblia ${ }^{45}$, as suas obras contribuíram

44 Poderíamos assinalar diversas obras, integradas nesta corrente, mas limitamo-nos aqui a destacar dois trabalhos, já tidos como clássicos, sobre a escravidão na América do Norte: Eugene D. Genovese, [1974] Roll, Jordan, Roll. The world the slaves made. Nova Iorque: Vintage Books, 1976; e Robert W. Fogel e Stanley L. Engerman, Time on the Cross. The économies of American Negro slavery. Boston: Little, Brown and Co., 2 vols., 1974.

45 Referimo-nos aquí a um trecho do Génesis (9: 20-27) em se relata um episodio célebre, passado com Noé, no qual este, agastado com o mais novo dos seus três filhos, Ham, teria amaldiçoado o filho deste, Canaan, a ser escravo dos seus próprios irmãos, condenando assim toda a sua descendência. A divulgação posterior da concepção segundo a qual Ham fora o responsável 
para fundamentar ideologicamente a exploração de base escravista. Aliás, há até quem defenda que "os letrados coloniais [essencialmente religiosos], tendo à frente os jesuitas, construíram uma outra versão ideológica da escravidão, um outro discurso que, em certo momento, propôs-se como alternativo ao "discurso pragmático " do mundo senhorial, sem, contudo, deixar de ser escravista "46.

A Economia Cristã dos Senhores no Governo dos Escravos, publicada em 1705, foi a primeira obra exclusivamente dedicada à temática da escravidão no Brasil. O seu autor, Jorge Benci, era um jesuíta italiano há alguns anos radicado na colónia ${ }^{47}$. As posições assumidas na sua obra encontravam-se porém muito distantes da atitude adoptada no final do séc. XVI por Miguel Garcia e Gonçalo Leite, também eles jesuítas, e ambos forçados a regressar à Europa por terem manifestado a sua discordância com o regime escravista e, designadamente, com a posse de escravos pela Companhia, denunciando o que entendiam ser a ilegitimidade dos cativeiros $^{48}$. A sua perspectiva era também distinta da que fora perfilhada por Alonso de Sandoval, outro jesuíta, que pouco menos de um século antes havia também publicado uma obra dedicada ao assunto, embora centrada na América espanhola ${ }^{49}$ : ao invés de Sandoval, cuja abordagem

pelo repovoamento do continente africano, após o Dilúvio, abriu caminho à associação entre negritude e escravidão; o debate sobre aquela passagem do Génesis manter-se-ia vivo pelo menos até ao séc. XIX, com os opositores e os defensores da escravidão a esgrimirem argumentos sobre a interpretação correcta a dar-lhe. Para uma visão actualizada da questão, ver: David M. Goldenberg, The Curse of Ham. Race and slavery in early Judaism, Christianity, and Islam. Princeton \& Oxford: Princeton University Press, 2003; e Stephen R. Haynes, Noahs Curse. The Biblical justification of American slavery. Oxford, Nova Iorque \& etc.: Oxford University Press, 2002. Este autor informa-nos que, na Europa Ocidental, a maldição de Noé já era invocada antes do advento da modernidade para explicar as origens da escravidão, a proveniência dos indivíduos de tez escura e o exílio dos hamitas para as regiões mais inóspitas da Terra mas acrescenta que "these aspects of malédiction were not integrated in an explicit justification for racial slavery until the flfteenth century, when dark-skinnedpeoples were enslaved by the Spanish and Portuguese, and the European slave stéréotypé was stabilized. Thus, only with the growth of the slave trade and the increasing reliance on sub-Saharan Africa as a source for slaves did the curse s role as a justification for racial slavery eclipse its function as a scriptural explanation of either "blackness" in particular or servitude in general" (p. 7).

46 Ronaldo Vainfas, Ob. cit., p. 17.

47 Para a referência completa, v. nota 17. Jorge Benci nasceu em Rimini no ano de 1650; em 1665, ingressou na Companhia, chegando ao Brasil em 1683; faleceu em Lisboa em 1708.

48 Serafim Leite, História da Companhia de Jesus no Brasil. Tomo II: Séc. XVI - a obra. Lisboa \& Rio de Janeiro: Livr. Portugália - Civilização Brasileira, 1938, pp. 227-229.

49 Alonso de Sandoval, SJ, [1627] De Instauranda Aethiopum Salute. A versão por nós consultada foi publicada sob o título de Un tratado sobre la esclavitud, com introdução, transcrição e tradução de Enriqueta Vila Vilar, Madrid: Alianza Editorial, 1987. Alonso de Sandoval nasceu em Sevilha; de 1605 até à sua morte, em 1652, viveu em Cartagena de índias (na actual Colômbia), 
privilegiava os escravos, fornecendo desde logo informações sobre o continente africano, as etnias das quais eram provenientes os que entravam por Cartagena, os seus costumes e crenças, bem como as vicissitudes do tráfico e as misérias a que estavam sujeitos os cativos no Novo Mundo, Jorge Benci dirigia-se, como o título da sua obra dava a perceber, essencialmente aos senhores ${ }^{50}$. Apoiando-se nos textos sagrados, na tradição patrística e nas obras de autores clássicos e modernos, definiu como objectivo para a mesma a explanação do que entendia como "regra, norma, e modelo, por onde se devem governar os senhores christãos para satisfazerem ás obrigações de verdadeiros senhores ”, isto é: a "economia cristã" 51 .

Seguindo de perto Santo Agostinho52, Jorge Benci justificava a escravidão como consequência do pecado original; na sua opinião, senhores e escravos encontravam-se ligados uns aos outros por uma "mutua, e reciproca correspondencia de obrigações Os escravos deviam obedecer aos seus senhores "com simplicidade de coração ", nisso agradando não tanto a eles, como ao próprio Deus; em contrapartida, os senhores tinham a obrigação de os tratar de forma justa, dando-lhes o alimento para o corpo e para a alma (mais o vestuário e o cuidado na doença), o trabalho, para que não se fizessem insolentes e merecessem o seu sustento, e, sempre que disso houvesse necessidade, o castigo, para que não errassem, segundo a máxima bíblica: "Panis, \& disciplina, \& opus servo ", 53 .

porto de entrada para muitos dos escravos que de África chegavam à América espanhola, ocupando-se em dar-lhes assistência espiritual, além de tratar os que desembarcavam em más condições de saúde. Na sua obra, denunciou as características do tráfico mas a preocupação central era, para ele, a salvação dos escravos e designadamente a questão do baptismo. O liv. 2. ${ }^{\circ}$, cap. IV, trata do modo "como se deven aver los esclavos en el servido de sus amos; y el que deven observar los amos, sirviéndose de sus esclavos "; nele, Sandoval defende que os maus exemplos em que incorrem os seus amos não eximem os escravos "de la obligación de servidumbre, a que su corta ventura y triste suerte los traxo ", ao mesmo tempo em que envectiva os senhores a que " abran los ojos, y vean la obligación que les corre, que no por ser amos, son señores absolutos, sin ley, obligación, ni Rey en orden a sus esclavos; pues este mando e imperio está como todas las demas cosas, sujeto a numero, peso y medida ", pp. 243-247.

50 Serafim Leite, A Companhia de Jesus e os pretos do Brasil. Lisboa: Ed. Brotéria, 1959, p. 3. A Economia Cristã dos Senhores no Governo dos Escravos reúne um conjunto de sermões pregados pelo seu autor na Baía, durante os últimos anos do séc. XVII. Embora, como dissemos, a maior parte da obra seja dirigida aos senhores, na segunda das quatro partes ou discursos de que ela se compõe, há uma "digressão exhortatoria aos parocos, para que ensinem a doutrina christãa aos escravos, como tem de obrigação ".

51 Jorge Benci, Ob. cit, p. 5.

${ }^{52}$ Gervase Corcoran, OSA, Ob. cit., especialmente pp. 69-71.

53 Jorge Benci, Ob. cit., pp. 5-8. 
Em relação a este último aspecto, o autor não deixa aliás margem para dúvidas: nasuaopinião, "para trazer bem domados, e disciplinados os escravos, he necessario que o senhor lhes não falte com o castigo, quando elles se desmandão, e fazem por onde o merecem " ${ }_{54}$. Consciente de que estas palavras poderiam ser tidas como incompatíveis com o propósito por ele próprio enunciado de "defender a causa dos escravos contra os senhores, que os maltratão ", justificava-a com o carácter vicioso dos cativos e com a sua alegada propensão para a rebeldia.

Segundo Benci, a punição dos faltosos devia obedecer a um conjunto de regras, cuidadosamente definidas para evitar que os senhores pecassem não só por excesso, como por defeito. O castigo imerecido deveria ser inteiramente banido - o que vale dizer que as situações em que os senhores puniam os seus escravos "não por razão, senão por fantasia " eram mais ou menos frequentes na colónia - e nenhum escravo devia ser punido sem que antes lhe fosse dada a oportunidade de se justificar mas nenhuma falta deveria também ficar sem castigo, a menos que se tratasse de culpas leves e erros cometidos sem dolo nem malícia mas apenas devido à "pouca capacidade, e natural rudeza dos pretos ", porque esses seriam antes motivo de compaixão e pretexto para instruir os cativos sobre o modo de os evitar. Além disso, os castigos deveriam ser aplicados com moderação, porque, dizia o jesuíta, "o escravo callejado com o castigo, já não o teme; eporque o não teme, não lhe aproveita ", isto é: o recurso demasiado frequente aos castigos, como forma de punição dos escravos, diminuiria necessariamente o impacto dos mesmos; deixando de ser tidos como acções exemplares, destinadas a infundir temor e respeito, converter-se-iam em actos rotineiros da vida nas fazendas ${ }^{55}$. Por outro lado, o uso de rigor excessivo por parte dos senhores era propício à rebelião, instigando as fugas de escravos e a formação subsequente de quilombos, a partir dos quais eram lançados ataques que punham em causa a segurança dos colonos, perturbando a economia das regiões «infectadas».

54 Ibidem, p. 123. A questão dos castigos é abordada no Discurso III, "em que se traita da terceira obrigação, que tem os senhores para com os servos ", pp. 122-196. Os elementos que a seguir apresentamos baseiam-se na análise do que nele se contém, remetendo assim para as referidas páginas.

$55 O$ autor chega a comparar o castigo com a guerra, porque à semelhança do que se passa com esta, também aquele i(mais póde temido, que experimentado ". Na verdade, diz, "emquanto o escravo não tomou o pulso ao castigo, e não sabe o que péza, he tal o medo, e horror, que lhe tem, que treme, e sua só com a consideração que seu senhor o poderá castigar: porém depois que o experimenta (e muito mais, se he por costume) pouco a pouco lhe perde o medo, e temor, e lhe endurece em tanta maneira a pelle como crestada, ou callejada, que o mesmo he castiga lio, que malhar (como dizeis) em ferro frio ". Ibidem, p. 144. 
As modalidades de que podia revestir-se o castigo eram outro dos aspectos abordados pelo autor: as injurias verbais e as maldições, correntemente usadas pelos senhores e, no dizer de Benci sobretudo pelas senhoras, para «mimosear» os seus escravos eram, na sua opinião, inteiramente ilícitas, um "intolerável abuso ", que além de ofender a religião, não tinha qualquer eficácia, porque os escravos "pouco ou nenhum caso " faziam dessas palavras. Já as sevícias que, no dizer do autor, transfiguravam os homens em "brutos", eram um castigo indigno da natureza humana e a razão pela qual na Antiguidade os imperadores romanos teriam julgado prudente tomar medidas no sentido de restringir o poder dos senhores, segundo o princípio, classificado por Benci como admirável, de que "convém ao bem publico, que ninguem uze mal, nem ainda do seu Das suas palavras se deduz que o autor não só justificava a intervenção do poder central nesta matéria, como a considerava mesmo necessária. As iniciativas recentes da Coroa para evitar os excessos cometidos pelos senhores no castigo dos escravos, das quais estava a par, forneceram-lhe aliás o pretexto para tecer rasgados elogios à acção do monarca, na pessoa de D. Pedro II ${ }^{56}$.

Como deveriam então agir os senhores para punir os delitos que efectivamente o justificassem? Antes de mais, não podiam deixar-se dominar pelos sentimentos: o castigo devia ser, com efeito, "moderado pela razão, e não governado pela paixão ", pois só assim se preveniriam os abusos. A que se referia o autor, ficamo-lo a saber quando, dirigindo-se directamente aos senhores, os interpelava perguntando "se he castigo racionavel queimar, ou atanazar (que tam impio, e cruel he este genero de castigo) com lacre aos servos: cortar-lhes as orelhas, ou os narizes: marca lios nos peitos, e ainda na cara: abrazar-lhes os beiços, e a bocea com tições ardentes? ”, assegurando, de resto, que havia outras práticas ainda mais desumanas a que os senhores teriam o hábito de recorrer e que por pudor não mencionava ${ }^{57}$. As consequências resultantes de tais actos, essas sim, eram claramente enunciadas: além das rebeliões mais ou menos organizadas e

56 “Nesta parte porém não temos os Portuguezes que envejar a Roma os Adrianos, e Antoninos Pios, por ter dado Déos a Coroa de Portugal hum Rey, que esmerando-se em todas as mais virtudes, he singularíssimo na piedade. [...] por isso vemos, que Sua Magestade o Senhor Rey Dom Pedro (que Déos nos guarde) entre os cuidados, que pede tam dilatada Monarquia, parece não tem outro mais que o com que procura suavizar o jugo da servidão, e cattiveiro dos escravos, que vivem nesta, e nas mais Conquistas de Portugal. E no particular de que trattamos, he incrivel o zelo, que mostra, para que não haja excesso no castigo, que dão os senhores aos servos". Ibidem, pp. 171-172.

57 Sobre as punições de que eram alvo os cativos, ver: Artur Ramos, "Castigos de Escravos". Revista do Arquivo Municipal. São Paulo: Prefeitura do Município de São Paulo - Departamento de Cultura, ano IV, vol. XLVII, 1938:79-104; e José Alípio Goulart, Da Palmatória ao Patíbulo... 
da fuga pura e simples, havia também a dos que optavam pelo suicídio como uma solução viável, a única que lhes permitiria escapar definitivamente aos seus algozes. O castigo dos escravos não tinha senão como objectivo a "emenda de suas vidas" e era esse o princípio norteador pelo qual deveriam pautar-se os senhores, na sua relação para com eles. Os meios de que poderiam licitamente usar para os punir resumiam-se, portanto, aos açoites (aplicados com moderação e, se necessário, repartidos por várias sessões, em dias alternados $)^{58}$; se estes não surtissem o efeito desejado, poderiam ainda prendê-los, com recurso a grilhões e correntes que, usados com regra e moderação, eram mais eficazes do que os açoites, pois "[bastava] só que os [visse] o servo, para que se [reduzisse] e [mettesse] a caminho, e [viesse] à obediencia, e sujeição de seu Senhor". Se o delito fosse porém de tal forma grave que pedisse a aplicação da pena de morte, o senhor do escravo tinha o dever de entregá-lo à Justiça para que esta o julgasse, porque, dizia Jorge Benci, "o Senhor não he Senhor da vida do servo " e não o fazer seria uma ofensa grave, ao invés do que afirmavam aqueles para quem a entrega dos escravos à Justiça representava uma afronta à dignidade dos senhores ou, como no texto se diz, à sua "nobreza, e fidalguia " 59 .

58 De acordo com o Antigo Testamento, os açoites deviam ser proporcionais à culpa mas não poderiam exceder em número os 40. Jorge Benci admitia porém que podia haver “ delittos tam graves, e atrozes, que [merecessem] muito mayor numero de açoutes ", razão pela qual se dirigia aos senhores para os instruir sobre o modo como, em tais circunstâncias, deveriam castigar os seus escravos: "E para procederem como he justo, devem fazer neste caso, o que fazem os Medicos, quando receitão a purga ao enfermo debilitado, e fraco. Se a não póde levar toda de hum golpe sem perigo de mayor danno; dividindo-a em partes, mandão que se lhe dé assim dividida, de tal sorte; que em hum dia tome hua parte, outra em outro dia; e assim a vem o enfermo a tomar toda. Do mesmo modo se ha de haver o senhor com o escravo, quando o crime, que commetteo, merece mayor numero de açoutes, do que acabamos de dizer. Os açoutes são medicina da culpa: e se os merecerem os escravos em mayor numero do que de ordinario se lhes devem dar, dem-se lhes por partes, isto he, trinta, ou quarenta hoje, outros tantos daqui a dous dias, daqui a outros dous dias outros tantos: e assim dando-se lhes por partes, e divididos, poderão receber todo aquelle numero, que se o recebessem por junto em hum dia, chegarião a ponto ou de desfallecer dessangrados, ou de acabar a vida ". Jorge Benci, Ob. cit., pp. 185-186.

As Ordenações Filipinas previam a pena de açoites para os escravos culpados de delitos como fogo posto, furtos no valor de 400 réis ou mais até meio marco de prata e a participação em jogos de dados ou cartas e outros cuja realização era proibida. Os escravos pretos e mulatos que fossem encontrados sem companhia ou que para isso não tivessem ordem de seus senhores estavam impedidos de usar armas como facas e outras, sob pena de serem presos e do pagamento de 500 réis, a satisfazer pelo senhor; se este se recusasse a fazê-lo, o escravo seria açoitado. No início do séc. XVIII, este crime passou a ser punido com 10 anos de galés. Silvia H. Lara, Campos da Violência..., pp. 79-81. Por alvará de 24 de Janeiro de 1756, a pena de galés foi substituída pela de "cem assoites dados no Pelourinho e repetidos por dez dias alternados ". ANRJ, Secção de Documentos Históricos, Registo de Cartas Régias, Códice 63, vol. 2, fis. 197v.-198.

59 Para uma análise da obra de Joige Benci, ver também: Ronaldo Vainfas, Ob. cit., pp. 129-134. 
Em 1711, foi publicada uma outra obra dirigida aos proprietários coloniais, neste caso especifícamente aos senhores de engenho, a Cultura e Opulência do Brasil por Suas Drogas e Minas, de André João Antonii, nome usado pelo jesuíta João António Andreoni, tal como Benci italiano e também ele residente na Baía ${ }^{60}$. A sua obra divide-se em três partes: a segunda e a terceira abordavam demoradamente as questões relacionadas com a cultura da cana e com o fabrico e comercialização do açúcar, fornecendo ainda informações sobre as outras riquezas da colónia (a saber: o tabaco, as minas e a criação de gado) mas na primeira, em que tratava do senhor de engenho e de todos os que vivendo sob o seu domínio intervinham no processo produtivo, há uma secção intitulada "Como se há de haver o senhor do engenho com seus escravos "61, em que era abordada a questão dos castigos. Apesar de reconhecer que os escravos "são as mãos e os pés do senhor do engenho " e que não se lhes devia faltar com "o que pertence ao sustento, vestido e moderação do trabalho ", nem com a assistência na doença ou, mais importante ainda, a doutrina, como muitas vezes se fazia, o autor advertia também, referindo-se especifícamente aos mulatos, que "não se lhes há de dar tanto a mão que peguem no braço, e de escravos se façam Senhores". A regra era aliás válida para todos, porque no Brasil se costumava dizer que "para o escravo são necessários três PPP, a saber, pau, pão epano ", ou seja: castigo, alimentação e vestuário. Com uma posição semelhante à de Benci, Antonii mostrava-se igualmente crítico em relação à aplicação indiscriminada de castigos, motivada pelo "ânimo vingativo" dos senhores, e ao uso de "instrumentos de muito rigor"-, reiterava porém que os delitos cometidos pelos escravos não deviam passar sem punição, prescrevendo para isso os "açoites moderados " e aprisão com correntes ou no tronco. Em causa estava não só a preservação dos valores cristãos e em particular da caridade, como a necessidade de evitar as perturbações resultantes da fuga de escravos e dos atentados contra a vida dos senhores (muitas vezes com o recurso a feitiços), para além da fuga sem remédio que era o suicídio ${ }^{62}$.

60 André João Antonii, [1711] Cultura e Opulência do Brasil por Suas Drogas e Minas. Estudo biobibliográfico de Afonso d'Escragnolle Taunay. Belo Horizonte: Itatiaia/Edusp, 1982 (3.a). O Pe. Andreoni nasceu em Luca, na Toscana, em 1649; ingressou na Companhia de Jesus em 1667; em Roma, conheceu o Pe. António Vieira, tendo-o acompanhado na sua viagem para o Brasil em 1681; faleceu na Báa, de cujo colégio chegou a ser reitor, em 1716. Palmira Morais Rocha de Almeida, Dicionário de Autores no Brasil Colonial. Lisboa: Colibri, 2003, pp. 64-66.

${ }^{61}$ André João Antonii, Ob. cit., pp. 31-33. As considerações que a seguir tecemos remetem para estas páginas.

62 Ver também Ronaldo Vainfas, Ob. cit., pp. 134-141 (especialmente pp. 138-141, em que o autor analisa o cap. XII do livro III da Cultura e Opulência do Brasil por Suas Drogas e Minas, submetido ao título "Do que padece o açúcar desde o seu nascimento na cana, até sair do Brasil ", pp. 58-59, como uma alegoria destinada a ilustrar o sofrimento dos escravos). 
Em 1758, quase meio século volvido sobre o aparecimento da Economia Cristã, deu-se a publicação do Etiope Resgatado, a segunda obra integralmente dedicada ao tema da escravidão no Brasil colonial. O seu autor era Manuel Ribeiro Rocha, sacerdote e advogado, natural de Lisboa e, ao que sabemos, durante longos anos morador na Baía 63 . Escrito a pensar nos comerciantes envolvidos no tráfico e nos próprios senhores de escravos, o texto estabelecia um conjunto de regras pelas quais se deveria pautar a sua actuação, discutindo a legitimidade dos cativeiros, tal como eram praticados em África, com o recurso a argumentos de ordem jurídica e aos textos clássicos do pensamento cristão ocidental $^{64}$. Na verdade, embora seja muitas vezes identificado como um precursor do abolicionismo e o primeiro grande defensor da liberdade dos negros no Brasil, Ribeiro Rocha não propôs a eliminação do sistema escravista, defendendo, isso sim, a redução do período de cativeiro a um máximo de 20 anos, segundo o princípio de que, através da compra, o senhor não adquiria a propriedade dos seus escravos mas apenas um direito de penhor, que cessaria quando estes the devolvessem o valor pelo qual os havia adquirido. $\mathrm{Na}$ sua opinião, embora a maioria dos cativos o fosse sem que para tal houvesse qualquer base legítima, a salvação de uma morte certa às mãos do inimigo, numa das muitas guerras que atingiam o continente, e a possibilidade da salvação eterna por intermédio do Cristianismo, justificavam, quer legalmente, quer sob o ponto de vista teológico, o «resgate» dos africanos. Ligando a escravidão à salvação do corpo e da alma dos cativos, Ribeiro Rocha deixava assim perceber que a «libertação» de que na sua obra falava deveria dar-se no interior do próprio sistema, não colocando em risco os interesses dos proprietários, nem o funcionamento da economia colonial. No entanto, à semelhança de Benci, também ele

63 Manuel Ribeiro Rocha, [1758] Etíope Resgatado. Empenhado, sustentado, corrigido, instruído e libertado. Discurso teológico-jurídico. Sobre a libertação dos escravos no Brasil de 1758. Introdução crítica de Paulo Suess. Petrópolis \& São Paulo: Vozes/CEHILA, 1992.

64 A legitimidade dos títulos de cativeiro constituiu uma preocupação central para os autores que, na Idade Moderna, reflectiram sobre a organização e funcionamento do sistema escravista. A discussão, que envolveu teólogos e juristas, processou-se inicialmente em tomo da captura dos índios no Novo Mundo e continuou após a sua substituição pelos africanos, como força de trabalho ao serviço dos colonos. O nascimento, a guerra justa e a compra para escapar a uma morte certa eram algumas das fontes de escravos normalmente aceites como legítimas; no caso dos africanos, a impossibilidade de determinar com precisão as condições em que se processava a sua redução ao cativeiro e, portanto, a legitimidade do mesmo, era porém muitas vezes invocada para desculpabilizar os proprietários americanos, que seriam vítimas inocentes de comerciantes sem escrúpulos, adquirindo os seus escravos de boa fé, sem ter conhecimento das ilegalidades que eram praticadas nos portos de embarque, do outro lado do Atlântico. Ver, p. ex.: Domingos Maurício, SJ, “A Universidade de Évora e a escravatura”, Sep. Didaskalia, n. ${ }^{\circ}$ 7, 1978: 153-200. 
defendia o princípio da reciprocidade de deveres entre o senhor e os seus escravos. Algumas cartas enviadas por Ribeiro Rocha ao Pe. Domingos de Sousa, que na qualidade de procurador-geral representava a Província do Brasil em Portugal, revelam aliás que os jesuítas se empenharam de forma muito activa na publicação desta e das outras obras do autor, reunindo mesmo o dinheiro necessário para a impressão do Etíope Resgatado 65 .

Dos escravos esperava-se, portanto, trabalho e obediência e que restituíssem aos seus senhores o preço pago pelo resgate; as obrigações destes para com eles consistiam, na opinião de Ribeiro Rocha, em sustentá-los, corrigi-los e dar-lhes instrução. O castigo ${ }^{66}$, cuja necessidade era justificada pelo carácter dos próprios escravos, devia ser porém ministrado com prudência e, para respeitar os princípios cristãos, teria que ser "bem ordenado quanto ao tempo; bem ordenado quanto à causa; bem ordenado quanto à qualidade; bem ordenado quanto à quantidade; e bem ordenado quanto ao modo Criticando a actuação habitual dos senhores, na relação com os cativos, opunha à sua "Teologia Rural " a "Teologia Cristã", cujas ideias-chave se encontravam expressas naquela fórmula. Seguindo de perto a tradição do Cristianismo e os princípios a esse respeito estabelecidos pelo Direito Romano, considerava que os escravos faltosos não deviam ser punidos de imediato para que o castigo não fosse inspirado pela cólera mas sim ministrado com "brandura e caridade nenhum escravo devia ser, além disso, castigado sem que para tal houvesse causa, sendo assim totalmente condenável o procedimento adoptado pelos senhores que, logo que os adquiriam, mandavam açoitar rigorosamente os seus escravos, a pretexto de evitar que se fizessem rebeldes. Ao argumento segundo o qual cada um podia dispor do que era seu como quisesse, respondia o autor com os limites impostos pelas leis divinas e humanas, sublinhando que os castigos imoderados não só eram prejudiciais para a república, como ofendiam a condição humana do escravo, que era por natureza igual ao senhor e ambos unidos na servidão a Deus. Quanto à

65 IAN/TT, Cartório dos Jesuítas, Maço 97, does. n. ${ }^{\circ}$ 110,126,129,143 e 166: cartas enviadas da Baía, entre 8 de Setembro de 1757 e 15 de Setembro de 1758. Nelas, Ribeiro Rocha agradece a "boa vontade, trabalho, disvello, e zêlo " do Pe. Domingos de Sousa nas diligências que conduziram à publicação do Etíope Resgatado, cujo original lhe fora enviado por intermédio do Pe. Mestre Manuel dos Santos e do procurador João da Penha, do Colégio da Baía, de quem diz serem os "protectorez" da sua obra. O primeiro dos dois escreveu ao procurador-geral da Província em 12 de Setembro de 1758 uma carta na qual referia explícitamente ter sido ele quem conseguiu o dinheiro para a impressão (doc. $n .^{\circ} 158$ ).

66 Esta questão é tratada na Quinta Parte da obra, sob o lema "Do que respeita à correção ", pp. 90-106. Os elementos que a seguir apresentamos resultam da análise das referidas páginas, para as quais remetemos. 
qualidade do castigo a aplicar, a palmatoria, a disciplina, o cipó e a prisão eram considerados admissíveis, excluindo-se o uso de bordões e de quaisquer outros instrumentos "grossos, epesados Apunição deveria ser, além disso, proporcional à culpa e, de preferência, inferior à que na lei era prescrita para respeitar o princípio do amor ao próximo, especialmente no caso dos açoites, de que no Brasil com frequência se abusava. O castigo, para ser eficaz, não poderia ser excessivo, nem quanto às palavras, nem quanto aos actos, sendo que, em relação a este aspecto, se dizia explicitamente que os senhores deveriam abster-se de fustigar os seus escravos "pelo rosto, pelos olhos, pela cabeça, e pelas mais partes irregulares " do corpo, dando assim a entender que se tratava de práticas comuns. A preocupação central consistia, uma vez mais, em garantir a convivência harmoniosa entre senhores e cativos e preservar o modo de produção escravista. Os escravos bem tratados, dizia-se, seriam "bons amigos " dos seus senhores; caso contrário, se não fugissem para escapar aos maus tratos, ficariam sendo seus "inimigos de porta adentro A relação entre uns e outros devia, em suma, pautar-se pelo equilíbrio, para que "nem os senhores, por rigorosos, [deixassem] de ser amados; nem também, por benévolos, [deixassem] de ser temidos, e respeitados "'67.

Embora não se trate aqui de discutir as posições historicamente assumidas pela Igreja relativamente à questão do escravismo, nem a existência ou não de incompatibilidade entre os princípios da doutrina cristã e a exploração assente no domínio do homem pelo homem, parece-nos contudo bastante significativo notar que as ideias defendidas no séc. XVIII pelos autores cujo pensamento acabamos de expor, ainda que de forma sucinta, não apresentam diferenças assinaláveis em relação às que no início da era cristã se encontravam nas obras dos padres da Igreja68. Muitas vezes explicitamente citados, as suas interpretações foram, na verdade, apropriadas pelos jesuítas e por outros, como Manuel Ribeiro Rocha, que não o sendo deles se achava próximo ${ }^{69}$, adaptadas ao escravismo

67 Para uma análise do Etíope Resgatado e das ideias nele expressas pelo seu autor, ver também: Maria José Gomes Páris Dias, Manoel Ribeiro Rocha. Escravidão e recta consciência (1758). Porto: Universidade Portucalense, 1996 (dissertação de Mestrado); Ronaldo Vainfas, Ob. cit., pp. 141-148.

Sobre a importância do castigo nas obras de Jorge Benci, Antonii e Ribeiro Rocha, ver Silvia H. Lara, Campos da Violência..., pp. 45-56.

68 Restituto Sierra Bravo, Doctrina Social y Económica de los Padres de la Iglesia. Colección general de documentos y textos. Madrid: COMPI - Compañía Bibliográfica Española, SA, 1967.

69 Além dos três autores por nós mencionados, outros houve que abordaram a problemática da escravidão africana no Brasil, sobretudo a partir de meados do séc. XVII, altura em que, segundo Ronaldo Vainfas \{Ob. cit., p. 87), se teria dado uma "inflexão ideológica ", que viria a traduzir-se no desenvolvimento de projectos visando o controlo social dos escravos, a par de 
moderno e utilizadas como chave interpretativa para «1er» a realidade colonial. Apoiando-se em autores como Santo Agostinho, São João Crisóstomo, Tomás de Aquino e outros; nos textos bíblicos por eles mencionados, como a já citada passagem do Génesis, o Eclesiastes ou as epístolas de São Paulo; bem como em autores da Antiguidade clássica, com destaque para Aristóteles e, em menor grau, Séneca, as obras cujo conteúdo acabamos de analisar constituíram, em suma, momentos-chave na formulação daquilo a que já se chamou um "projecto escravista-cristão "70, o qual teria como intuito reformar a instituição e, de uma forma mais ampla, a própria sociedade colonial, a partir de imagens idealizadas do senhor e do cativo, em que o propósito de dominação se articulava com o respeito pelos valores cristãos para incutir nos senhores uma nova consciência, de matriz católica, ao mesmo tempo em que se procurava estimular a obediência dos escravos como forma de agradar a Deus, perante o qual não havia distinções, e alcançar a libertação na eternidade. O escravo cristão era pois, nesta perspectiva, um escravo submisso que aceitava a sua condição e a ela se sujeitava, sofrendo o destino que lhe coubera em sorte tal como Cristo o fizera, porque embora o seu corpo não o fosse a sua alma permanecia livre; o cativeiro terrestre era afinal a via milagrosa que o arrancara às trevas do obscurantismo para o conduzir à salvação, por intermédio do Cristianismo. Tomando como modelo a família patriarcal, em que o senhor era também um pai e como tal amado e respeitado, tendo para com os seus escravos as mesmas obrigações que tinha para com os seus filhos, condenava-se a promiscuidade (quer entre os senhores e as suas escravas, quer dos escravos entre si), o concubinato e a prostituição; ao mesmo tempo, censurava-se os senhores, lembrando-lhes o destino reservado na Bíblia para os hebreus, levados para a Babilónia como cativos em pena dos maus tratos infligidos aos seus escravos, prometendo-se o castigo divino aos que para

reflexões sobre os movimentos de rebelião. O Pe. António Vieira foi a este respeito pioneiro mas, entre os nomes que são mencionados pelo autor (pp. 87-91), encontram-se também: Nuno Marques Pereira, o autor do Compêndio Narrativo do Peregrino da América [1728], admirador confesso de Vieira; Sebastião da Rocha Pita, senhor de engenho na Baía, onde foi educado pelos jesuítas, e autor da História da América Portuguesa [ 1730]; Domingos Loreto Couto, beneditino, autor dos Desagravos do Brasil e Glórias de Pernambuco [1758], com um capítulo dedicado às guerras para o derrube do quilombo de Palmares. A estes poderia ainda acrescentar-se D. José Joaquim da Cunha de Azeredo Coutinho, natural do Rio de Janeiro, bispo de Pernambuco e inquisidor-geral à altura em o Santo Ofício foi extinto no nosso país, autor de uma obra, publicada em 1808, sobre a justiça do resgate dos escravos em África e de um projecto de lei "para obrigar o senhor a que não abuse da condição do seu escravo", cf. Silvia H. Lara, Campos da Violência..., pp. 47-48; e Palmira Morais Rocha de Almeida, Ob. cit., pp. 152-156.

${ }^{70}$ Ronaldo Vainfas, Ob. cit., especialmente pp. 93-124. 
com eles se comportavam "pior do que se fossem infiéis"1". Numa palavra, embora encontrassem justificação teórica para a escravização dos africanos, cujo contributo era tido como indispensável para o desenvolvimento da colónia, os letrados (com os jesuítas à cabeça) tinham dificuldade em articular o tratamento que viam ser-lhes dispensado com os princípios do Cristianismo; trataram, por isso, de enunciar um conjunto de regras que tomassem a servidão simultaneamente "mais estável ou duradoura, mais produtiva e menos violenta "12 *.

3. Avaliar a extensão alcançada pela sua influência é tarefa que não se nos afigura fácil mas a produção teórica a que acima fizemos menção teve com certeza consequências importantes na organização da vida na colónia - senão em termos práticos, pelo menos no que diz respeito às normas emanadas do poder civil e religioso - fornecendo um modelo a seguir no relacionamento com os escravos, para além, é claro, de justificar ideologicamente a validade do sistema. Dois anos volvidos sobre a publicação da Economia Cristã, foram aprovadas as Constituições Primeiras do Arcebispado da Baía ${ }^{73}$ que, durante muito tempo, constituíram o texto orientador sobre o qual assentaria a actuação da Igreja na colónia. Nele, encontram-se diversas referências aos escravos: a propósito dos sacramentos, instruíam-se os senhores para terem o cuidado de os fazer baptizar, recomendando-se-lhes igualmente que não colocassem entraves ao matrimónio dos mesmos e que tomassem as providências necessárias para lhes assegurar um enterramento condigno. Claramente influenciado por Benci, cuja obra aparecia diversas vezes citada ao longo do texto, o diploma atribuía uma importância particular à doutrinação dos cativos, com recomendações, quer aos senhores, quer aos párocos, para zelarem pela instrução religiosa dos escravos e a publicação de um catecismo ou Breve instrucçam dos mysterios da Fe, accomodada ao modo de fallar dos escravos do Brasil, para serem catequisados por ella ${ }^{14}$. A iniquidade em que assentava o próprio sistema não

${ }^{71}$ André João Antonii, SJ, Ob. cit., p. 32.

72 Ronaldo Vainfas, $O b$. cit., p. 100. Sobre os aspectos aqui tratados, ver também: Isabel Castro Henriques e Louis Sala-Molins (org.), Déraison, Esclavage et Droit. Les fondements idéologiques et juridiques de la traite négrière et de l'esclavage. Paris : Éditions UNESCO, 2002 ; e Rafael de Bivar Marqúese, Feitores do corpo, missionários da mente. Senhores, letrados e o controle dos escravos nas Américas, 1660-1860. São Paulo: Companhia das Letras, 2004.

73 Constituições primeyras do Arcebispado da Bahia feytas, e ordenadas pelo illustrissimo, e reverendissimo senhor D. Sebastião Monteyro da Vide, arcebispo do dito Arcebispado, \& do Concelho de Sua Magestade, propostas, e aceytas em o Synodo Diecesano, que o dito senhor celebrou em 12 de Junho do anno de 1707. Coimbra. No Real Collegio das Artes da Companhia de Jesus. 1720.

«Ibidem, Liv. 3. ${ }^{\circ}$, tít. XXXII, pp. 230-233. 
era, pelo contrario, objecto de condenação e a violência a ele implícita praticamente ignorada, com referências muito escassas aos maus tratos de que eram alvo os cativos.

Assim, a propósito do matrimónio, declarava-se que os senhores não podiam impedi-lo, nem por isso "tratarpeyor " a seus escravos ou vendê-los "para outros lugares remotos ", onde os respectivos cônjuges não se lhes pudessem juntar; caso contrário, pecariam mortalmente, sendo responsabilizados pelas culpas dos escravos "que por esse temor se [deyxavão] muytas vezes estar, \& permanecer em estado de condemnação”. Os senhores deviam, portanto, abster-se de “com ameaços, \& mao tratamento ” impedir o legítimo matrimónio dos cativos, os quais era certo que, "posto que [casassem], [ficavão] escravos como de antes erão, \& obrigados a todo o serviço de seu senhor"15. Por outro lado, entre as pessoas a quem era negada a imunidade da Igreja, encontravam-se os escravos que fugiam para se livrar do cativeiro, mesmo quando se tratasse de cristãos; acrescentava-se porém que os que fugissem para escapar à "desordenada severidade " com que eram tratados pelos seus senhores, não lhes deveriam ser restituídos sem que estes se comprometessem a não os tratar mal ou a vendê-los, nos casos em que por Direito eram obrigados a fazê-lo ${ }^{76}$.

A legislação episcopal referente ao Bispado do Rio de Janeiro, por nós consultada, dá-nos igualmente conta das preocupações da Igreja relativamente à salvação da alma dos cativos, com a responsabilização directa dos senhores no que a essa matéria dizia respeito e a reiteração frequente de críticas ao seu comportamento, quer pelo mau exemplo que com a sua vida desregrada e viciosa forneciam aos escravos que se encontravam sob o seu domínio, quer porque não lhes davam outra alternativa senão a de trabalhar ao Domingo, impedindo-os de frequentar a catequese, ou porque abandonavam os seus corpos, depois de mortos, não lhes proporcionando, como deviam, as exéquias a que todo o cristão tinha direito ${ }^{77}$. Tal como as Constituições do Arcebispado, a legislação produzida pelos prelados do Rio de Janeiro, durante o séc. XVIII, não revelava porém qualquer preocupação com os padecimentos físicos de que eram vítimas os escravos: em 1760, D. Fr. António do Desterro [1745-1773] dirigia-se, pelo contrário, à abadessa do convento de $\mathrm{N}^{\mathrm{a}}$ Sra. da Conceição da Ajuda, na própria cidade do Rio de Janeiro, dando-lhe ordem para castigar "severissimamente " qualquer escrava que fosse "tão petulante, que se [atrevesse] a offender ainda

»Ibidem, Liv. $1^{\circ}$, tit. LXXI, pp. 132-133.

7‘ Ibidem. Liv. $4 .^{\circ}$, tit. XXXIII, p. 287.

${ }^{77}$ Arquivo da Cúria Metropolitana do Rio de Janeiro (daqui em diante, ACMRJ), Portarias e Editais, Liv. 1 (1742-1838); Portarias e Ordens Episcopais, Liv. 1 (1750-1761) e 3 (1779-1830). 
levissimamente a qualquer religioza, e a não [tratasse] com a reverencia, e submissão devida, ou [fizesse] acção algua contra a immunidade da clausura, e sagrado da Religião ", ameaçando com a prisão no aljube aquelas em que os castigos não surtissem efeito ${ }^{78}$.

Excepção feita às pastorais, a legislação destinava-se, principalmente, ao «consumo» intemo da instituição mas os sermões, pregados publicamente aos fiéis, eram um instrumento importante para a difusão dos princípios da Igreja. São célebres os sermões pregados, no séc. XVII, pelo Pe. António Vieira aos escravos da Baía: neles, exortava os seus ouvintes a "dar infinitas graças a Deus" pelo "milagre" de tê-los tirado das suas terras, onde viviam como gentios, para os levar ao Brasil, onde, sendo instruídos na Fé, viveriam como cristãos e se salvariam; subvertendo os princípios da relação escravista, ao mesmo tempo em que se insurgia contra o tráfico, deplorando a sorte dos cativos, pelo "desumano trabalho " a que nos engenhos se encontravam sujeitos, apontava-lhes as semelhanças entre a sua vida e a do próprio Cristo, aconselhando-os a sofrer com paciência e abnegação os padecimentos que lhes estavam reservados, porque reservada tinham também a salvação na eternidade, ao contrário dos senhores, tiranos e cruéis, cuja perdição era certa ${ }^{79}$. Ao valorizar a liberdade interior, António Vieira contribuía, de forma significativa, para a dignificação do escravo mas, ao mesmo tempo, desvalorizava a servidão dos corpos, enaltecendo o sofrimento como o meio para alcançar a libertação definitiva: em suma, os cativos deveriam viver passivamente o destino que outrém reservara para si, fazendo, isso sim, por libertar-se do cativeiro espiritual do pecado, infinitamente pior que o do corpo, mesmo que para tal fossem obrigados a desobedecer às ordens dos seus senhores, recebendo com resignação o castigo que inevitavelmente se seguiria ${ }^{80}$.

D. Fr. António de Guadalupe, um franciscano, que, entre 1725 e 1740, se manteve à frente dos destinos da Igreja no Bispado do Rio de Janeiro, também abordou a problemática da escravidão em alguns dos seus sermões, embora sem a

${ }^{78}$ ACMRJ, Portarias e Ordens Episcopais, Liv. 1 (1742-1838), fis. 128-129.

" António Vieira, SJ, Obras Escolhidas. Sermões (II). Prefácio e notas de António Sérgio e Hemâni Cidade. Lisboa: Livr. Sá da Costa Editora, vol. XI, 1996 (2.a), pp. 1-95 (sermões XIV e XXVII). Ver também: Ronaldo Vainfas, Ob. cit., pp. 125-129; António José Saraiva, "Le père António Vieira SJ et la question de Pesclavage des noirs au XVII.e siècle". Annales. Économies, sociétés, civilisations. Paris: Armand Colin, n. ${ }^{\circ}$ 6, nov.-dez. 1967: 1289-1309; e José Carlos Sebe Bom Meihy, "A ética colonial e a questão jesuítica dos cativeiros indio e negro". Afro-Ásia. Salvador: Univ. Federal da Baía, n. ${ }^{\circ} 23$, 1998/99: 9-27.

80 “O que haveis de fazer éconsolar-vos muito com estes exemplos; sofrer com muita paciência os trabalhos do vosso estado, dar muitas graças a Deus pela moderação do cativeiro a que vos trouxe, e sobre tudo aproveitar-vos dele para o trocar pela liberdade efelicidade da outra vida, que não passa, como esta, mas há-de durar para sempre Ibidem, p. 91. 
projecção e brilhantismo do Pe. Vieira. Os aspectos por si tratados não eram aliás novos: criticava os senhores pela falta de zelo em relação à saúde espiritual dos cativos - "Ahpobres escravos, alguns, em que mãos viéstes dar! Ah tyrannos senhores, que conta haveis de dar das suas almas? " - e, dirigindo-se aos "senhores habitadores do mundo novo ", condenava a actuação dos que faziam dos seus escravos (e, em particular, das escravas) cúmplices ou instrumento dos seus próprios pecados, insurgindo-se contra os "costumes da terra", que sustentavam os vícios e a ociosidade da camada dominante. Os senhores, dizia, tinham a obrigação de "castigar, de emendar, de reprimir peccados daquelles, que [tinham] a seu cargo, e lhe [estavam] sujeitos",' colocando a ênfase na servidão do pecado (à qual opunha a liberdade encontrada por quem serve a Cristo), acrescentava mesmo que os senhores deviam dar vazão à sua ira, e não reprimi-la, sob pena de fomentar culpas mais graves: a omissão do castigo seria pois, ela própria, um pecado ${ }^{81}$.

Em 1759, quando se deu o sequestro dos bens dos jesuítas, por ordem do marquês de Pombal, a fazenda de Santa Cruz, situada nos arredores do Rio de Janeiro, possuía mais de mil escravos de um e de outro sexo, pertencentes aos padres da Companhia. O inventário que, na altura, foi realizado pelas autoridades dá-nos conta de um plantei pujante, bem vestido e alimentado, que se via aumentar com o nascimento de meia centena de crianças em cada ano, fruto de casamentos incentivados pelos padres; os doentes tinham duas enfermarias à sua disposição; todos os demais possuíam roças, onde cultivavam os produtos para o seu sustento, que também podiam vender, à semelhança das criações; o

81 "Sermoens do excellentissimo, e reverendissimo D. Fr. Antonio de Guadalupe, religioso menór da Santa Provincia de Portugal, bispo do Rio de Janeiro, e nomeado de Visêu. Tomo I. E parte primeira Quaresmal. Obra posthuma; dados à luz pelo cuidado de fr. Manoel de S. Damaso, chronista da mesma Provincia, patricio, e amigo muy favorecido do excellentissimo author, e por elle dedicados a Maria SS. Nossa Senhora debaixo do soberano, e precioso título da Senhora dos Anjos da Porciuncula, na presensa da sua especiosissima imagem do coro do real convento de S. Francisco da cidade de Lisboa. Lisboa: na officina dos herdeiros de Antonio Pedrozo Galram. Anno MDCCXLIX”, pp. 200-205, 264-265, 335-350.

"Sermoens do excellentissimo, e reverendissimo D. Fr. Antonio de Guadalupe, religioso menór da Santa Provincia de Portugal, bispo do Rio de Janeiro, e nomeado de Visêu; Tomo IV. Eparte unica Adventual. Obra pósthuma. Dados á luz pelo cuidado de Fr. Manoel de S. Damaso, chronista da mesma Provincia, patricio, e amigo muy favorecido do excellentissimo author; e por elle dedicados a Maria SS. Nossa Senhora, debaixo do soberano, e precioso titulo da Senhora dos Anjos da Porciuncula, na presença da sua especiosissima imagem do coro do real convento de S. Francisco da cidade de Lisboa. Lisboa. Na officina dos herdeiros de Antonio Pedrozo Galram. MDCCLIV", pp. 52-55. 
trabalho variava em função das condições do tempo, ajustando-se às capacidades dos próprios cativos; as missas eram diárias e o mesmo se passava com a doutrina. Os escravos eram, em geral, obedientes e as suas faltas castigadas “сом açoutes em moderado numero, palmatoradas, e tronco [...] sem que [fosse] neceçario, e menos conveniente espanca lios com paus, de que [rezultariam] aleyjoes, e menos aptidão para o servisso" 82 .

À semelhança dos jesuítas, as outras ordens religiosas que se encontravam presentes na colónia também recorriam abundantemente aos serviços dos escravos, que, ao que parece, eram, em geral, relativamente bem tratados nas suas fazendas e engenhos ${ }^{83}$. Entre os proprietários laicos, muitos haveria com certeza que, ou por motivos de racionalidade económica, ou pela força das suas próprias convicções religiosas, tratavam os seus escravos com moderação mas, como vimos, os abusos eram constantes e, chegando muitas vezes a ser desumanos, tomavam ainda mais intolerável o fardo, já de si pesado, da servidão. Os padecimentos sofridos por Luzia da Silva Soares, a cujo infortúnio no início fizemos referência, dão-nos disso um testemunho pungente: acusada de feitiçaria e, por isso, severamente punida, viu-se obrigada a confessar, assumindo por força uma identidade que não era a sua; daí em diante, seria o alvo de todas as suspeitas e, por qualquer pretexto, sujeita a terríveis "martírios". A sua vida tomou-se assim de tal forma insuportável que, como mais tarde confessaria perante os inquisidores, "por tantas vezes se tinha visto, com tal dezesperação, e aperto, que por varias vezes se quis matar com hum canivete, de que Deos Nosso Senhor foi servido livra la". Sobreviveu para relatar a sua história, certamente igual à de muitos outros, e, com o seu percurso de coragem e sofrimento, denunciar o arbítrio dos senhores, que muitas vezes se comportavam como verdadeiros algozes, e, de um modo geral, a iniquidade do sistema escravista, que através das suas palavras se revela como irremediavelmente trágico ${ }^{84}$

82 IAN/TT, Desembargo do Paço - Corte, Estremadura e Ilhas, Avulsos, mç. 2038 (fazenda de Sta Cruz: "Formalidade que se pratica no tracto da Fazenda, e dos escravos delia").

83 D. Mateus Rocha, OSB, "Escravos e Beneditinos". Revista do Instituto Histórico e Geográfico Brasileiro. Rio de Janeiro, 149 (358), jan.-mar. 1988: 16-21; Stuart B. Schwartz, "The plantations of St. Benedict: the Benedictine sugar milis of colonial Brazil". The Américas, vol. XXXIX, n. ${ }^{\circ}$ 1, jul. 1982: 1-22; e Venâncio Willeke, OFM, "Senzalas de Conventos". Revista do Instituto Histórico e Geográfico de São Paulo, vol. 27, 1976: 355-376.

84 IAN/TT, Inquisição de Lisboa, Proc. n. ${ }^{\circ} 11$ 591, especialmente fis. 47-59. Veja-se também o Proc. n. ${ }^{\circ} 16$ 687, sobre os desmandos praticados na Baía pelo mestre de campo Garcia de Ávila Pereira de Aragão, senhor da Casa da Torre, e a análise que dele faz Luiz Mott, "Terror na Casa da Torre", in João José Reis (org.), Escravidão e Invenção da Liberdade. São Paulo: Editora Brasiliense, 1988, pp. 17-32. 


\section{Fontes e bibliografía}

\section{Fontes manuscritas}

a) Brasil:

1.1. Arquivo Nacional do Rio de Janeiro (ANRJ):

1.1.1. Secção de Documentos Históricos:

Registo de Cartas Régias: Códice 63, vol. 1 (1662-1724)

Códice 63, vol. 2 (1725-1777)

Códice 63, vol. 3 (1662-1741)

1.2. Arquivo da Cúria Metropolitana do Rio de Janeiro (ACMRJ):

1.2.1. Pastorais e Editais: Liv. 1 (1742-1838)

1.2.2. Portarias e Ordens Episcopais: Liv. 1 (1750-1761)

Liv. 3 (1779-1830)

b) Portugal:

1.2. Instituto dos Arquivos Nacionais/Torre do Tombo (1AN/TT):

1.2.1. Cartório dos Jesuítas:

Maços: 97 (doc. n. $\left.{ }^{\circ} 110,126,129,143,158,166\right)$

1.2.2. Desembargo do Paço - Corte, Estremadura e Ilhas:

Avulsos: mç. 2038

1.2.3.Inquisição de Lisboa:

Processos: 11 591, 16687

1.2.4.Papéis do Brasil:

Avulsos: mç. 2, n. $^{\circ} 2$

\section{Fontes impressas}

ANTONIL, André João, SJ - [1711] Cultura e Opulência do Brasil por suas Drogas e Minas. Estudo bibliográfico de Afonso d'Escragnolle Taunay. Belo Horizonte: Itatiaia/Edusp, $1982\left(3 .^{\mathrm{a}}\right)$.

BENCI, Jorge, SJ - Economia christãa dos senhores no governo dos escravos.

Deduzida das palavras do capitulo trinta, e tres do Ecclesiastico: Panis, \& disciplina, \& opus servo: reduzida a quatro discursos morais pelo padre Jorge Benci de Arimino da Companhia de Jesu, missionário da Provincia do Brasil. E offerecida à alteza real do serenissimo gran duque de Toscana pelo padre Antonio Maria Bonucci da mesma Companhia. Em Roma, na officina de Antonio de Rossi na Praça de Ceri. 1705. 
Constituições primeyras do Arcebispado da Bahia feytas, e ordenadas pelo illustrissimo, e reverendissimo senhor D. Sebastião Monteyro da Vide, arcebispo do dito Arcebispado, \& do Concelho de Sua Magestade, propostas, e aceytas em o Synodo Diecesano, que o dito senhor celebrou em 12 de Junho do anno de 1707. Coimbra. No Real Collegio das Artes da Companhia de Jesus. 1720.

GUADALUPE, D. Fr. António de - "Sermoens do excellentissimo, e reverendissimo D. Fr. Antonio de Guadalupe, religioso menór da Santa Provincia de Portugal, bispo do Rio de Janeiro, e nomeado de Viseu. Tomo I. E parte primeira Quaresmal. Obra posthuma; dados à luz pelo cuidado de ff. Manoel de S. Damaso, chronista da mesma Provincia, patricio, e amigo muy favorecido do excellentissimo author, e por elle dedicados a Maria SS. Nossa Senhora debaixo do soberano, e precioso título da Senhora dos Anjos da Porciuncula, na presensa da sua especiosissima imagem do coro do real convento de S. Francisco da cidade de Lisboa. Lisboa: na officina dos herdeiros de Antonio Pedrozo Galram. Anno MDCCXLIX".

- "Sermoens do excellentissimo, e reverendissimo D. Fr. Antonio de Guadalupe, religioso menór da Santa Provincia de Portugal, bispo do Rio de Janeiro, e nomeado de Viséu; Tomo IV. E parte unica Adventual. Obra pósthuma. Dados á luz pelo cuidado de Fr. Manoel de S. Damaso, chronista da mesma Provincia, patricio, e amigo muy favorecido do excellentissimo author; e por elle dedicados a Maria SS. Nossa Senhora, debaixo do soberano, e precioso titulo da Senhora dos Anjos da Porciuncula, na presença da sua especiosissima imagem do coro do real convento de S. Francisco da cidade de Lisboa. Lisboa. Na officina dos herdeiros de Antonio Pedrozo Galram. MDCCLIV".

ROCHA, Manuel Ribeiro - [1758] Etiope Resgatado. Empenhado, sustentado, corrigido, instruído e libertado. Discurso teológico-jurídico. Sobre a libertação dos escravos no Brasil de 1758. Introdução crítica de Paulo Suess. Petrópolis \& São Paulo: Vozes/CEHILA, 1992.

SANDOVAL, Alonso de, SJ - [1627] De Instauranda Aethiopum Salute. Un tratado sobre la esclavitud. Introdução, transcrição e tradução de Enriqueta Vila Vilar. Madrid: Alianza Editorial, 1987.

VIEIRA, Antonio, SJ - Obras Escolhidas. Sermões (II). Prefácio e notas de António Sérgio e Hemâni Cidade. Lisboa: Livr. Sá da Costa Editora, vol. XI, $1996\left(2 .{ }^{a}\right)$. 


\section{Bibliografia:}

\subsection{Obras de referência}

ALMEIDA, Palmira Morais Rocha de - Dicionário de Autores no Brasil Colonial. Lisboa: Colibri, 2003.

Dicionário Houaiss da Língua Portuguesa. Edição electrónica: Instituto Antônio Houaiss-Editora Objetiva, 2001.

\subsection{Artigos, ensaios e estudos}

ANDRÉS-GALLEGO, José - História da Gente Pouco Importante. Lisboa: Estampa, 1993.

BRAVO, Restituto Sierra - Doctrina Social y Económica de los Padres de la Iglesia. Colección general de documentos y textos. Madrid: COMPI Compañía Bibliográfica Española, SA, 1967.

CORCORAN, Gervase, OSA - Saint Augustine on Slavery. Roma: Institutum Patristicum «Augustinianum», 1985.

FLORENTINO, Manolo \& GÓES, José Roberto - A Paz das Senzalas. Famílias escravas e tráfico atlântico, Rio de Janeiro, c. 1790-c. 1850. Rio de Janeiro: Civilização Brasileira, 1997;

—\& MACHADO, Cacilda (org.) - Ensaios Sobre a Escravidão (i). Belo Horizonte: Editora UFMG, 2003.

FREYRE, Gilberto - Casa Grande \& Senzala. Formação da família brasileira sob o regime da economia patriarcal. Lisboa: Ed. «Livros do Brasil», 1957 (edição portuguesa).

GORENDER, Jacob - O Escravismo Colonial. São Paulo: Ática, 1978.

GOULART, José Alípio - Da Palmatória ao Patíbulo (castigos de escravos no Brasil). Rio de Janeiro: Conquista/INL, 1971.

- Da Fuga ao Suicídio. Aspectos de rebeldia dos escravos no Brasil. Rio de Janeiro: Conquista/INL, 1972.

HAYNES, Stephen R. Haynes - Noah 's Curse. The Biblical justification of American slavery. Oxford, Nova Iorque \& etc.: Oxford University Press, 2002.

HENRIQUES, Isabel Castro e Sala-Molins, Louis (org.) - Déraison, Esclavage et Droit. Les fondements idéologiques et juridiques de la traite négrière et de l'esclavage. Paris : Éditions UNESCO, 2002.

HESPANHA, Antonio (org.) - Justiça e Litigiosidade: História e prospectiva. Lisboa: Fundação Calouste Gulbenkian, 1993. 
LARA, Silvia Hunold - "Do mouro cativo ao escravo negro: continuidade ou ruptura?", Anais do Museu Paulista, XXX, 1980/1981, pp. 375-398;

- Campos da Violência: escravos e senhores na Capitania do Rio de Janeiro, 1750-1808. Rio de Janeiro: Paz e Terra, 1988;

- Legislação Sobre Escravos Africanos na América Portuguesa. Madrid: Fundación Histórica Tavera, 2000.

LEITE, Serafim - Historia da Companhia de Jesus no Brasil. Lisboa \& Rio de Janeiro: Livr. Portugália - Civilização Brasileira/Instituto Nacional do Livro, 10 vols., 1938-1950.

- A Companhia de Jesus e os pretos do Brasil. Lisboa: Ed. Brotéria, 1959.

MARQUESE, Rafael de Bivar - Feitores do corpo, missionários da mente.

Senhores, letrados e o controle dos escravos nas Américas, 1660-1860.

São Paulo: Companhia das Letras, 2004.

MEIHY, José Carlos Sebe Bom - "A ética colonial e a questão jesuítica dos cativeiros índio e negro". Afro-Ásia. Salvador: Univ. Federal da Baía, n. ${ }^{\circ}$ 23,1998/99: 9-27.

"Penser la Violence. Perspectives philosophiques, historiques, psychologiques et sociologiques" (dossier temático). Revue Internationale des Sciences Sociales. Paris : UNESCO/érès, 132, mai. 1992.

RAMOS, Artur - "Castigos de Escravos". Revista do Arquivo Municipal.

São Paulo: Prefeitura do Município de São Paulo - Departamento de Cultura, ano IV, vol. XLVII, 1938: 79-104.

REIS, João José (org.) - Escravidão e Invenção da Liberdade. São Paulo: Editora Brasiliense, 1988.

ROCHA, D. Mateus, OSB - "Escravos e Beneditinos". Revista do Instituto Histórico e Geográfico Brasileiro. Rio de Janeiro, 149 (358), jan.-mar. 1988: 16-21.

SARAIVA, António José - "Le père António Vieira SJ et la question de 1'esclavage des noirs au XVII.e siècle". Annales. Economies, sociétés, civilisations. Paris: Armand Colin, n. ${ }^{\circ}$ 6, nov.-dez. 1967: 1289-1309.

SCHWARTZ, Stuart B. - "Résistance and accommodation in Eighteenth-Century Brazil”. Hispanic American Historical Review, n. ${ }^{\circ}$ 57, 1977: 69-81.

- "The plantations of St. Benedict: the Bénédictine sugar milis of colonial Brazil”. The Américas, vol. XXXIX, n. ${ }^{\circ}$ 1,jul. 1982: 1-22.

VAINFAS, Ronaldo - Ideologia \& Escravidão. Os letrados e a sociedade escravista no Brasil Colonial. Petrópolis: Vozes, 1986.

WILLEKE, Venâncio, OFM - "Senzalas de Conventos". Revista do Instituto Histórico e Geográfico de São Paulo, vol. 27, 1976: 355-376. 